\title{
AN EMPIRICAL ASSESSMENT OF THE RISK-TAKING CHANNEL
}

\author{
Yener Altunbas $^{\S}$, Leonardo Gambacorta* and David Marques-Ibanez ${ }^{* *}$
}

\begin{abstract}
This paper investigates the relationship between monetary policy and bank risk-taking. Using a unique database that includes quarterly balance sheet information for listed banks operating in the European Union and the United States in the last decade, we find evidence that unusually low interest rates over an extended period of time cause an increase in banks' risk taking. This result holds for a wide range of measures of risk, as well as macroeconomic and institutional controls.
\end{abstract}

JEL classification: E44, E55, G21.

Keywords: bank risk, credit crisis, risk-taking channel, monetary policy.

\section{Contents}

1. Introduction 2

2. Monetary policy and risk-taking: theory and evidence ............................................... 3

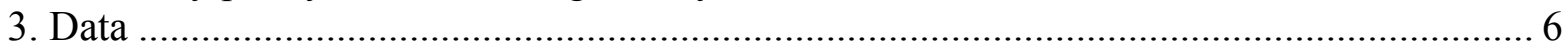

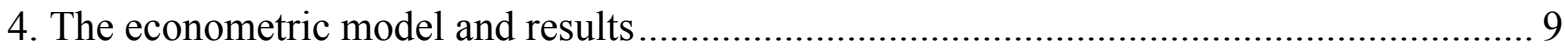

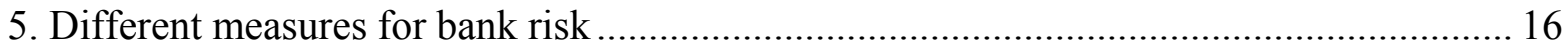

6. Testing for non-linear effects, business expectations and regulatory differences.............. 18

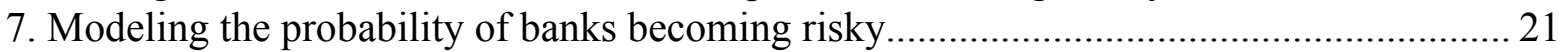

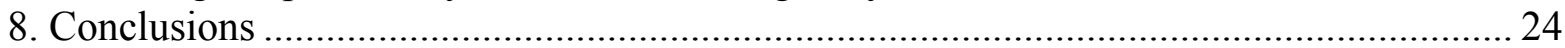

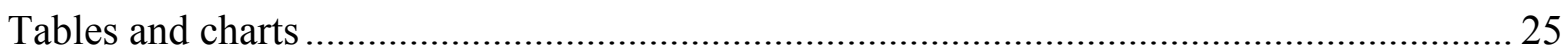

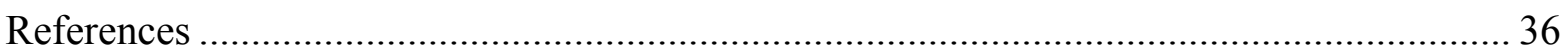

$\S$ Centre for Banking and Financial Studies, Bangor University.

* Bank for International Settlements, Monetary and Economics Department.

** European Central Bank, Financial Research Division. 


\section{Introduction ${ }^{1}$}

In the aftermath of the burst of the dotcom bubble, many central banks lowered interest rates to ward off recession. Prior successes in taming higher levels of inflation strengthened the support for a large number of monetary authorities to lower interest rates, keeping them below the levels suggested by historical experience (Taylor, 2009). While excessive liquidity could encourage bank risk-taking, this financial stability aspect was not seen as particularly threatening for two main reasons. First, most central banks around the world have progressively shifted towards tight inflation objectives as their best contribution to fostering economic development (Svensson and Woodford, 2004). Second, financial innovation had, for the most part, been regarded as a factor that would strengthen the resilience of the financial system by resulting in a more efficient allocation of risks (Greenspan, 2005). In this context, the financial stability implications of monetary policy actions were deemed of minor importance.

Although it is difficult to state that monetary policy has been the main cause of the current crisis, it could have contributed to its build-up. There are two main ways in which low interest rates may influence bank risk-taking. First, low interest rates affect valuations, incomes and cash flows, which in turn can modify how banks measure risk (Adrian and Shin, 2009a; 2009b; Borio and Zhu, 2008). Second, low returns on investments, such as government (risk-free) securities, may increase incentives for banks, asset managers and insurance companies to take on more risk for behavioral, contractual or institutional reasons, for example to meet a target nominal return (Brunnermeier, 2001; Rajan, 2005).

\footnotetext{
${ }^{1}$ We would like to thank Rodrigo Alfaro, Santi Carbo, Richard Davis, Claudio Borio, Steven Cecchetti, Carsten Detken, Matthias Drehmann, Marie Hoerova, Gabriel Jimenéz, Michael King, Angela Maddaloni, Phil Molyneux, Robert McCauley, Stefano Neri, Steven Ongena, Alexander Popov, Jonathan Rose, Carlotta Rossi, Klaus Schaeck, Ludger Schuknecht, Alessandro Secchi, Kostas Tsatsaronis, Christian Upper, Goetz Von Peter and John Wilson for their comments and useful discussions. We are also grateful for the comments of conference participants at the Bank for International Settlements workshop entitled "Monetary Policy and Financial Stability" and the European Central Bank workshop "Monetary policy transmission mechanism in the euro area in its first 10 years". Our thanks also to Francesca Fabbri, and Marco Lo Duca for their help constructing indicators of bank risk derived from stock market prices. Jean-Paul Genot, Michael Huetl, Samuel Lopes and Pablo Garcia Luna were also most helpful in guiding us to the relevant databases. The opinions expressed in this paper are those of the authors only and in no way involve the responsibility of the European Central Bank or the Bank for International Settlements. Email addresses: Y.Altunbas@bangor.ac.uk, Leonardo.Gambacorta@bis.org and David.Marques@ecb.int.
} 
In this paper we analyze empirically the relationship between monetary policy and risk-taking by banks. Using a comprehensive database of quarterly balance sheet information and risk measures for listed banks operating in the European Union and the United States in the last decade, we find evidence that unusually low interest rates over an extended period of time contributed to an increase in banks' risk-taking. The paper is innovative and relevant in two respects: first, it analyzes the effectiveness of the risk-taking channel at the international level using a wide range of publicly available indicators for bank risk; second, it relies on an in-depth analysis of the possible determinants of banks risk prior and during the financial turmoil. In order to disentangle the effects of monetary policy from other factors, we have to delve into other possible causes of changes in banks' risk. Hence we also account for bankspecific characteristics (size, liquidity, capitalization, lending portfolios, profitability), macroeconomic factors (GDP, housing and equity prices, structure of the yield curve), and institutional characteristics at the national level (competition, risk appetite, intensity of regulation).

The remainder of this paper is organized as follows. The next section discusses how monetary policy could impact on banks' risk-taking. Section 3 describes the data used in the analysis, while Section 4 presents the econometric model and main results. Section 5 verifies the robustness of the findings, considering a more complete term structure for bank risk. In Section 6 we check for non-linear effects, business expectations, differences in the levels of bank regulation and competition. The probability for a bank to become risky during the crisis is modeled in Section 7, and the last section summarizes the study's main conclusions.

\section{Monetary policy and risk-taking: theory and evidence}

From a historical perspective, easy monetary conditions are a classical ingredient in boombust type business fluctuations (Fisher, 1933; Hayek, 1939; Kindleberger, 1978). Low interest rates could indeed induce financial imbalances by means of a reduction in risk aversion by banks and other investors. This part of the monetary transmission mechanism has been recently referred to as the risk-taking channel and looks at how changes in monetary policy rates affect either risk perceptions or risk-tolerance (Borio and Zhu, 2008). 
There are a number of ways in which low interest rates can influence risk-taking. The first is through their impact on valuations, incomes and cash flows. ${ }^{2}$ A reduction in the policy rate boosts asset and collateral values, which in turn can modify bank estimates of probabilities of default, loss given default and volatilities. For example, low interest rates by increasing asset prices tend to reduce asset price volatility and thus risk perception: since a higher stock price increases the value of equity relative to corporate debt, a sharp increase in stock prices reduce corporate leverage and could thus decrease the risk of holding stocks. ${ }^{3}$ This example can be applied to the widespread use of Value-at-Risk methodologies for economic and regulatory capital purposes (Danielsson et al (2004)). As volatility tends to decline in rising markets, it releases risk budgets of financial firms and encourages positiontaking. A similar argument is provided by Adrian and Shin (2009b) who stress that changes in measured risk determine adjustments in bank balance sheets and leverage conditions and this, in turn, amplifies business cycle movements. ${ }^{4}$

The second way the risk-taking channel may operate is through the 'search for yield' (Rajan, 2005). Low interest rates may increase incentives for asset managers to take on more risks for a number of factors. Some are psychological or behavioral in nature such as the socalled money illusion: investors may ignore the fact that nominal interest rates may decline to compensate for lower inflation. Others may reflect institutional or regulatory constraints. For example, life insurance companies and pension funds typically manage their assets with reference to their liabilities. In some countries, liabilities are linked to a minimum guaranteed nominal rate of return or returns reflecting long-term actuarial assumptions rather than the current level of yields. In a period of declining interest rates, they may exceed the yields available on highly-rated government bonds. The resulting gap can lead institutions to invest in higher-yielding, higher-risk instruments. More generally, financial institutions regularly enter into long-term contracts committing them to produce relatively high nominal

\footnotetext{
2 This is close in spirit to the familiar financial accelerator, in which increases in collateral values reduce borrowing constraints (Bernanke et al, 1996). Adrian and Shin (2009) claim that the risk-taking channel differs from and strengthens the financial accelerator because it focuses on amplification mechanisms due to financing frictions in the lending sector. Fostel and Geanakoplos (2009) link the leverage cycle with contagion.

${ }^{3}$ For this reason the link between asset prices and asset price volatility is sometimes described as the leverage effect. See Pagan and Schwert (1990) and the studies cited in Bollerslev et al (1992).

${ }^{4}$ Lower interest rates may reduce the incentives to screen borrowers, thereby effectively encouraging banks to relax their credit standards. From a modeling perspective, this mechanism is equivalent to the impact of increased competition on lending standards (Ruckes, 2004; Dell'Ariccia and Marquez, 2006).
} 
rates of return. And a similar mechanism could be in place whenever private investors use short-term returns as a way of judging manager competence and withdraw funds after poor performance (Shleifer and Vishny, 1997; Brunnermeier and Nagel, 2004). More broadly, the link between low interest rates and excessive risk-taking is also influenced by the structure of managerial bonus schemes and deficiencies in supervision and regulation (Ackerman et al., 1999; Kouwenberg and Ziemba, 2007).

A third possible set of effects of monetary policy on risk-taking may operate through habit formation. In their work on the equity risk premium, Campbell and Cochrane (1999) show that investors become less risk-averse during economic expansions because their consumption increases relative to normal levels, so that an easing of monetary policy may, by increasing real economic activity, decrease the degree of investors' risk aversion. This mechanism is in line with the findings from literature on asset-pricing models, which predict higher credit spreads in the long run after periods of lower interest rates (Longstaff and Schwartz, 1995; Dufresne et al., 2001).

Finally, the risk-taking may also be influenced by the communication policies of a central bank and the characteristics of policymakers' reaction functions. For example, a high degree of central bank predictability with regard to future policy decisions can reduce market uncertainty and thus lead banks to take on more risks. In this way agents' perception that the central bank will ease monetary policy in the event of bad economic outcomes could lower the probability of large downside risks, thereby producing an insurance effect. For this reason, Diamond and Rajan (2009) argue that in good times monetary policy should be kept tighter than strictly necessary based on current economic conditions, in order to diminish banks' incentive to take on liquidity risk. In a forward looking manner agents can also choose to increase their interest rate exposure to macroeconomic conditions making monetary policy time inconsistent not for the standard inflation bias reason but rather due to the higher macroeconomic sensitivity to interest rates (Farhi and Tirole, 2009).

Turning to the empirical evidence, there are only a handful of studies that try to test directly for the existence of a risk-taking channel. The paper by Jiménez et al (2009) uses micro data of the Spanish Credit Register over the period 1984-2006 to investigate whether the stance of monetary policy has an impact on the level of risk of individual bank loans. They find that low interest rates affect the risk of the loan portfolio of Spanish banks in two 
conflicting ways. In the short term, low interest rates reduce the probability of default of the outstanding variable rate loans, by reducing interest burdens of previous borrowers. In the medium term, however, due to the higher collateral values and the search for yield, banks tend to grant more risky loans and, in general, to soften their lending standards: they lend more to borrowers with a bad credit history and with more uncertain prospects. Overall, these results suggest that low interest rates reduce credit risk in banks portfolios in the short term - since the volume of outstanding loans is larger than the volume of new loans - but they raise it in the medium term.

Ioannidou et al (2009) take a different, perspective and analyze whether the risk-taking channel works not only on the quantity of new loans but also on their interest rates. The authors investigate the impact of changes in interest rates on loan pricing using Bolivian data over the period 1999-2003. They find that, when interest rates are low, not only do banks increase the number of new risky loans but they also reduce the rates they charge to riskier borrowers relative to what they charge to less risky ones. And interestingly, the reduction in the corresponding spread (and the extra risk) is higher for banks with lower capital ratios and more bad loans. Data on individual loan and borrower characteristics is however confidential in most occasions and available only for a handful of countries who maintain a credit register.

Our approach is complementary. We take an international perspective and focus on the banking sector by relying on publicly available information to most central banks and supervisors. We use an extensive and unique database which matches balance sheet data at a quarterly frequency for listed banks in the European Union and US with an array of individual proxies of bank risk. In order to insulate the effects of monetary policy we control for a wide set of alternative factors that could impact on risk-taking attitude including bankspecific characteristics, macroeconomic conditions, differences in the intensity of bank supervision, investors' risk aversion, changes in bank competition perception, the housing price boom-bust cycle and excessive lending growth.

\section{Data}

The sample comprises quarterly balance sheet information taken from Bloomberg over the period 1998-2008. Unlike the overwhelming majority of international banking studies 
which employ annual data, this research uses quarterly data which are more appropriate for measuring the short-term impact of monetary policy changes on bank risk. The initial sample includes information from an unbalanced panel of more than 1,100 listed banks from 16 countries: Austria, Belgium, Denmark, Germany, Greece, Finland, France, Ireland, Italy, Luxembourg, the Netherlands, Portugal, Spain, Sweden, the United Kingdom and the United States. In order to ensure as much comparability as possible in accounting standards, we included only listed banks (which are usually very large and often cross-listed in several stock exchanges) and focused on standard indicators (i.e. balance sheet size, capital to asset ratio, liquidity ratio, total lending, return on assets).

The variable accounting for bank risk is an important element of the analysis. Hence, the data on individual bank financial statements have been matched with a wide array of publicly available and widely used measures accounting for bank risk. The first one is given by the expected default frequency $(E D F) . E D F$ is a well-known, forward-looking indicator of credit risk, computed by Moody's KMV, which builds on Merton's model to price corporate bond debt (Merton, 1974). ${ }^{5}$ EDF figures are regularly used by financial institutions, investors, central banks and regulators to monitor the health of the financial system (IMF, 2009a; ECB, 2009). More crucially, it seems to have done quite well as a predictor of default during the recent credit crisis (see, for instance, Munves et al., 2009). The evolution of the one-year $E D F$ for the countries in the sample is reported in Chart 1.

The analysis of $E D F$ is supplemented by including additional measures to account for bank risk derived from stock market information. The objective is to decompose bank risk into two measures accounting for idiosyncratic (individual) and systemic (market wide) elements. Thus we can ascertain whether monetary policy influences each individual bank's risk position on top of systemic considerations. More specifically this helps clarify bank attitudes towards risk-taking, independent of the developments in the banking system as a whole, which might be due to shocks common to all financial intermediaries. To tackle this, two complementary approaches have been used. The first is based on a simple Capital Asset Pricing Model $(C A P M)$. This allows for the calculation of specific beta coefficients for each

\footnotetext{
${ }^{5}$ Dwyer and Qu (2007) provide further details on the construction of EDFs. For an empirical application of $E D F$ s see, for instance, Garlappi et al. (2007).
} 
bank in the sample for each specific quarter, using daily data. The idiosyncratic component is then simply given by the unexplained component of each regression for bank $i$ over each quarter $t$ (IDSC1). ${ }^{6}$ The second approach follows Campbell et al. (2001), who build on Merton (1980) and decompose historical stock market movements into total market, banking sector and individual bank level volatility. As in Campbell et al. (2001), the latter is interpreted as the idiosyncratic risk of each individual bank for each given quarter (IDSC2). ${ }^{7}$ The top left hand side of Table 1 shows the correlation between the different measures of bank risk used in this paper. The correlation is always positive and significant, but in many cases is significantly less than one.

Turning to the macroeconomic variables, the monetary policy rate is the threemonth interbank rate. This measure, unlike the interest rate on main refinancing operations, is able to capture the effect of the recent credit crisis on the actual cost of bank refinancing. ${ }^{8}$ The seasonally adjusted nominal GDP was obtained from the OECD Economic Outlook database, while Datastream is the source of stock market returns and interest rates. The slope of the yield curve is calculated as the difference between the ten-year government bond yields and the short term rate. Housing index nominal returns have been obtained from the Bank for International Settlements.

\footnotetext{
${ }^{6}$ The CAPM model is based on the following equation: $R_{i, k, t}=\beta_{\mathrm{i}, t}+R_{m, k, t}+\varepsilon_{i, t}$ where $R_{i, k, t}$ and $R_{m, k, t}$ are the individual bank $i$ and market wide $m$ logarithmic returns calculated for each country $k$ at quarter $t$. The term $\varepsilon_{i, t}$ is the bank specific residual. We use bank-level return data at daily frequency, including all traded banks represented in the Datastream broad banking index for each country. We included banks which were traded at one point during our period of study (for instance, so-called 'dead' banks resulting from acquisitions are also included). The broad Datastream indices are used as they are comparable across countries and have a very wide coverage. For the sake of simplicity, we follow Campbell et al. (2001) and assume that the zero-intercept assumption is reasonable in this context. We also rerun all calculations including a bank specific intercept with no changes in the main results. All estimations are available upon request.

${ }^{7}$ Campbell et al. (2001) calculate the decomposition of stock market volatility without imposing a parametric model to describe its evolution over time. By assuming that the different components (market, sector and individual) of stock market returns are orthogonal to one another, a simple variance decomposition can be undertaken to calculate each of these components of risk. Therefore individual bank idiosyncratic risk can be calculated as:

$\sum_{k=1}^{K} \sum_{q=1}^{Q} \sum_{t=1}^{T} \frac{\left(R_{i, k, q, t}-R_{B, k, q, t}\right)^{2}}{o b s}$

where $R_{i, t}$ and $R_{B, t}$ are, respectively, the individual bank $i$ and banking sector $B$ returns for each country $k$ at time $t$. The variable $o b s$ refers to the number of daily observations for each quarter available for bank $i$. All results are available upon request.

${ }^{8} \mathrm{We}$ also tried other measures of monetary policy rates with a lower maturity (overnight, one-month) and results remain unchanged.
} 
The initial sample consisted of more than 1,100 banks in 16 industrialized countries. Unfortunately, not all of the bank risk measures used in the study were available for all of these banks so it was decided to restrict the analysis to the 643 banks for which all the necessary information was available. Table 2 gives some basic information on the final dataset. From a macroeconomic point of view, this dataset is still extremely relevant because it represents around two-thirds of the total lending provided by banks in the European Union and the US. The average size of the banks in the sample is largest in the United Kingdom, Belgium and Sweden, and smallest in Finland and Greece. Equally, the average size of US banks is not very large because there is more information available for this country and many small banks are also listed. The averages of individual bank characteristics differ across countries. There are also differences in terms of capital and liquidity ratios, probably reflecting different competitive and institutional conditions, as well as different stages of the business cycle.

In Table 3, banks are grouped depending on their specific risk position, using one-year $E D F$ s. A 'high-risk' bank has the average $E D F$ of banks in the fifth quintile (i.e. $E D F_{H}$ is equal to 2.02\%); a 'low-risk' bank has the average $E D F$ of the banks in the first quintile $\left(E D F_{L}\right.$ is equal to $0.09 \%$ ). The first part of the table shows that high-risk banks are smaller, less liquid and less capitalized. The lower degree of liquidity and capitalization appears to be consistent with the higher risk of these banks. Additionally, low-risk banks make relatively fewer loans than high-risk banks, but the difference is not so remarkable.

\section{The econometric model and results}

Empirically, it is difficult to measure the impact of low interest rates on bank risk-taking. The main problem comes in trying to separate the effects of changes in monetary policy rates on two key areas: first, the risk of outstanding loans and, second, banks' incentives to take on new risk. As already discussed in Section 2, a reduction of interest rates to a level below the equilibrium rate causes a positive direct effect on lending portfolios (since households and firms pay a reduced interest rate on variable rate mortgages, the probability of their going into default declines) and an indirect negative effect because the 'search for yield' could cause an overall increase in new risk-taking. 
To tackle this identification problem, we have calculated different benchmark levels of interest rates through which to evaluate the relative stance of monetary policy. In particular, the following country-specific benchmark measures have been introduced:

a) the difference between the actual nominal short-term interest rate and that generated by a 'Taylor rule' with interest rate smoothing (TGAP) $;^{9}$

b) the difference between the actual nominal short-term interest rate and that generated by a standard "Taylor rule", using equal weights on output and inflation and no interest rate smoothing (TGAP2); ${ }^{10}$

c) the difference between the real short-term interest rate and the "natural interest rate" (NRGAP), calculated using the Hodrick-Prescott filter.

Chart 2 shows the three measures for the United States. In general, it was found that using a Taylor rule of type (a), with interest rate smoothing, tends to reduce the gap with respect to the nominal interest rate. This measure is also much less strongly correlated with bank $E D F$ than the other measures $\left(-0.10^{* * *}\right.$ against $-0.20 * * *$ and $\left.-0.18^{* * *}\right)$. In this paper, $T G A P$ is used as the main measure of relative monetary policy, with the aim of applying a more stringent criterion for testing for the existence of a risk-taking channel. In other words, since smoothing tends to reduce the magnitude of the channel that is being tested, if a risktaking channel is detected using the TGAP measure, the strength of this channel would be expected to be even more significant using a standard Taylor rule (TGAP2) or the natural interest rate $(N R G A P)$.

The baseline empirical model is given by the following equation:

\footnotetext{
9 The Taylor rule suggests a simple way of setting monetary policy (Taylor, 2001). In particular, the money market interest rate (i.e. federal funds rate in the US) is a positive function of both the difference between inflation $\left(\pi_{\mathrm{t}}\right)$ and its target level $\left(\pi^{*}\right)$, and the output gap: the gap between $G D P\left(y_{\mathrm{t}}\right)$ and its long-term potential non inflationary level $\left(y_{\mathrm{t}}^{*}\right)$. Algebraically, this can be written as $i_{\mathrm{t}}=\alpha+\beta_{\pi}\left(\pi_{\mathrm{t}}-\pi^{*}\right)+\beta_{\mathrm{y}}\left(y_{\mathrm{t}}-y_{\mathrm{t}}^{*}\right)+\gamma\left(i_{\mathrm{t}}-i_{\mathrm{t}-1}\right)$, where the last part of the equation represents interest rate smoothing and $\alpha$ is the real rate prevailing when output and inflation are at target levels $\left(r^{*}=i^{*}-\pi^{*}=\alpha-\pi^{*}\right)$. We set $\beta_{\pi}=1.5$ and $\beta_{\mathrm{y}}=0.5$. The interest rate smoothing parameter $\gamma$ has been set to 0.90 . The target inflation $\left(\pi^{*}\right)$ has been set to $2 \%$.

10 Following the standard set-up for a Taylor rule, we set $\beta_{\pi}=\beta_{\mathrm{y}}=0.5$ and $\gamma=0$. Also in this case the target inflation $\left(\pi^{*}\right)$ has been set to $2 \%$.
} 


$$
\begin{aligned}
\Delta E D F_{i, t}= & \alpha \Delta E D F_{i, t-1}+\sum_{j=0}^{1} \beta_{j} \Delta M P_{k, t-j}+\sum_{j=0}^{1} \gamma_{j} T G A P_{k, t-j}+\sum_{j=0}^{1} \delta_{j} \Delta G D P N_{k, t-j}+ \\
& +\sum_{j=0}^{1} \varphi_{j} S L O P E_{k, t-j}+\sum_{j=1}^{4} \phi_{j} S D+\varepsilon_{i, t}
\end{aligned}
$$

with $i=1, \ldots, N, \mathrm{k}=1, \ldots, 15$ and $t=1, \ldots, T$ where $\mathrm{N}$ is the number of banks, $k$ is the country and $T$ is the final quarter. Table 4 reports the summary statistics for the variables used.

In the baseline equation (1) the quarterly change of the Expected Default Frequency $(\triangle E D F)$ for bank $i$ in quarter $t$, is regressed on changes in the monetary policy indicator $(\triangle M P)$, the Taylor Rule Gap $(T G A P)$, nominal GDP growth rate $(\triangle G D P N)$, the steepness of the yield curve (SLOPE). Seasonal dummies (SD) have also been included in this specification. One lag of all the variables has been introduced in order to obtain white noise residuals.

We relate changes in bank EDFs to country-specific macro-variables because intermediation activity, which is the most important part of banks' business, is done principally towards residents. Nevertheless we are aware that a part of bank activities takes place on international markets and national conditions could be less important for a number of big European banks located in small countries. However, if this were the case we should observe a less significant link between changes in individual bank risk and low interest rates in the country where the bank is headquartered. In other words, if a risk-taking channel is detected using our identification strategy, the strength of this channel would be expected to be even more significant when controlling for multinational activity.

The main results of the analysis are reported in Table 5. The introduction of a lagged dependent variable among the predictors creates substantial complications in the estimation as the lagged dependent variable is correlated with the disturbance. Hence the models have been estimated using the GMM estimator developed for dynamic panel models by Arellano and Bover (1995) and Blundell and Bond (1998). This estimator ensures efficiency and consistency, provided that the models are not subject to serial correlation of order two and that the instruments used are valid (which is checked using the Sargan test). 
Table 5 shows that, ceteris paribus, the effects of changes in the short term monetary policy rate on banks' risk are positive. The overall quality of a loan portfolio indeed increases (banks' EDFs decrease) if interest rates are lowered. This is consistent with the finding of Jiménez et al. (2009) that lower interest rates reduce the credit risk of outstanding loans. The drop in the $E D F$ is probably reinforced by the reduction in bank funding liquidity cost after the decrease in short-term monetary interest rates (Diamond and Rajan, 2009; Adrian and Shin, 2009a).

The coefficient related to the TGAP variable is negative and significant, confirming the effect of a risk-taking channel: if the interest rate is below the benchmark rate, banks do take more risks. For example, taking the results from the baseline model in the first column, if the interest rate is 100 basis points below the value given by the Taylor rule, the average probability for a bank to go into default increases by $0.6 \%$ after a quarter and by $0.8 \%$ in the long run. This is a very rough estimate of such a probability and - since the model does not include controls for asset price dynamics and individual bank-specific characteristics (to be discussed below) - it represents an upper limit of the effect.

The coefficients for $\triangle G D P N$ are negative. Better economic conditions increase the number of projects becoming profitable in terms of expected net present value, thereby reducing the overall credit risk of the bank (Kashyap et al., 1993). Higher output growth reduces credit risk on both new and outstanding loans, in stark contrast to the differential effects of monetary policy.

Furthermore, the coefficients for the slope of the yield curve are negative. A steeper yield curve determines an increase in bank profits (a decrease in the $E D F$ ) because of the typical maturity transformation function performed by banks, since their assets have a longer maturity than liabilities. This is consistent with the findings of Albertazzi and Gambacorta (2009).

Since the Taylor rule gap could, in principle, give different indications with respect to other measures, the reliability of these baseline results have been tested using the natural rate gap; that is, the difference between the real short-term interest rate and the natural interest rate $(N R G A P)$. As shown in the second column of Table 5, results are very similar: the only difference is the magnitude of the coefficient for $N R G A P$, caused by the different average 
level of the two variables. As discussed at the beginning of this section, results are even more in favor of the existence of a risk-taking channel when using a simple Taylor rule with no interest rate smoothing and equal weights.

Improvements in borrowers' net worth and collateral are taken into account by introducing into the specification the evolution of asset prices:

$$
\begin{aligned}
\Delta E D F_{i, t}= & \alpha \Delta E D F_{i, t-1}+\sum_{j=0}^{1} \beta_{j} \Delta M P_{k, t-j}+\sum_{j=0}^{1} \gamma_{j} T G A P_{k, t-j}+\sum_{j=0}^{1} \delta_{j} \Delta G D P N_{k, t-j}+ \\
& +\sum_{j=0}^{1} \varphi_{j} S L O P E_{k, t-j}+\sum_{j=0}^{1} \mu_{j} \Delta H P_{k, t-j}+\sum_{j=0}^{1} \kappa_{j} \Delta S M_{k, t-j}+\sum_{j=1}^{4} \phi_{j} S D+\varepsilon_{i, t}
\end{aligned}
$$

where $\triangle H P$ and $\triangle S M$ are the quarterly changes in housing and stock market returns, respectively. Both asset returns are demeaned and adjusted for inflation. The introduction of these variables accounts for the effects of the standard 'financial accelerator' mechanism, through which financing frictions on firms and households amplify or propagate exogenous disturbances (Bernanke and Gertler, 1989). With a given bank risk aversion (or tolerance), the coefficients of both variables should be negative: a boost in asset prices increases the value of collateral and reduces overall credit risk.

However, the results presented in the third column of Table 5 show that only the coefficients for changes in stock market returns have the expected negative sign, while the opposite is detected for housing prices. This calls for further investigation into the relationship between changes in housing prices and bank risk.

Ellis (2008) points out that the recent credit crisis was triggered by credit losses on US mortgages. In the period under consideration, the United States seems to have built up a larger excess of housing supply, experienced a greater easing in mortgage lending standards, and ended up with a household sector that is more vulnerable to falling house prices. Some of these outcomes seem to have been driven by tax, legal and regulatory systems that encouraged households to increase their leverage and permitted banks to enable that development. Apart from the United States, there are other countries in the sample that experienced a boom-bust housing price cycle, namely Denmark, Ireland, Spain, Sweden and the United Kingdom (IMF, 2009b). Given this fact, we have included in the model (see below equation (3)) two interaction variables between each asset price and a dummy 
$(H P B B)$ that takes the value of 1 if the bank is based in one of the countries that experienced a boom-bust housing cycle and zero elsewhere.

$$
\begin{aligned}
\Delta E D F_{i, t}= & \alpha \Delta E D F_{i, t-1}+\sum_{j=0}^{1} \beta_{j} \Delta M P_{k, t-j}+\sum_{j=0}^{1} \gamma_{j} T G A P_{k, t-j}+\sum_{j=0}^{1} \delta_{j} \Delta G D P N_{k, t-j}+ \\
& +\sum_{j=0}^{1} \varphi_{j} S L O P E_{k, t-j}+\sum_{j=0}^{1} \mu_{j} \Delta H P_{k, t-j}+\sum_{j=0}^{1} \kappa_{j} \Delta S M_{k, t-j}+ \\
& +\sum_{j=0}^{1} \mu_{j}^{*} \Delta H P_{k, t-j} * H P B B+\sum_{j=0}^{1} \kappa_{j}^{*} \Delta S M_{k, t-j} * H P B B+\sum_{j=1}^{4} \phi_{j} S D+\varepsilon_{i, t}
\end{aligned}
$$

The fourth column of Table 5 shows that the positive link between housing prices and trends in bank risk is accounted for by developments in the housing market of those countries that experienced a boom-bust cycle. The coefficient $\mu_{j}$ for the remaining European countries, where the housing price bubble did not materialize (or was less pronounced), is indeed negative.

The link between bank risk and accommodative monetary policy could also be influenced by balance sheet characteristics that summarize the ability and willingness of banks to supply additional loans (Ehrmann et al., 2003). We have, therefore, introduced into the specification SIZE (the log of total assets; Kashyap and Stein, 1995), LIQ (securities and other liquid assets over total assets; Stein, 1998); and CAP (the capital-to-asset ratio; Kishan and Opiela, 2000; Van den Heuvel, 2002). The econometric model is therefore modified in the following way:

$$
\begin{aligned}
\Delta E D F_{i, t} & =\alpha \Delta E D F_{i, t-1}+\sum_{j=0}^{1} \beta_{j} \Delta M P_{k, t-j}+\sum_{j=0}^{1} \gamma_{j} T G A P_{k, t-j}+\sum_{j=0}^{1} \delta_{j} \Delta G D P N_{k, t-j}+ \\
& +\sum_{j=0}^{1} \varphi_{j} S L O P E_{k, t-j}+\sum_{j=0}^{1} \mu_{j} \Delta H P_{k, t-j}+\sum_{j=0}^{1} \kappa_{j} \Delta S M_{k, t-j}+ \\
& +\varpi S I Z E_{i, t-1}+\tau L I Q_{i, t-1}+\zeta C A P_{i, t-1}+\sum_{j=1}^{4} \phi_{j} S D+\varepsilon_{i, t}
\end{aligned}
$$

where all bank-specific characteristics refer to $t-1$ in order to avoid endogeneity bias.

The results are reported in the fifth column of Table 5. The effects of liquidity (LIQ) and capitalization $(C A P)$ on bank risk are negative. All other things being equal, liquid and 
well-capitalized banks are considered less risky by the market. The effect on size is contrary to the 'too big to fail' paradigm.

During the recent credit crisis not all banks have been equally affected and responsible. The banks which were predominantly affected were large institutions which moved away from traditional retail banking activities towards a business model that principally relied on the manufacturing, distribution and trading of new and complex securities (Panetta et al., 2009). Moreover, it has often been pointed out that these big banks in financial difficulties could have been "too big to be saved by their national governments alone" (Stiglitz, 2009). In order to check if the result on the size variable is driven by these effects during the crisis, the model has been adapted by including an interaction between the variable SIZE and a crisis dummy (CRISIS), which takes the value of 1 from 2007Q3 to 2008Q4 and zero elsewhere.

$$
\begin{aligned}
\Delta E D F_{i, t} & =\alpha \Delta E D F_{i, t-1}+\sum_{j=0}^{1} \beta_{j} \Delta M P_{k, t-j}+\sum_{j=0}^{1} \gamma_{j} T G A P_{k, t-j}+\sum_{j=0}^{1} \delta_{j} \Delta G D P N_{k, t-j}+ \\
& +\sum_{j=0}^{1} \varphi_{j} S L O P E_{k, t-j}+\sum_{j=0}^{1} \mu_{j} \Delta H P_{k, t-j}+\sum_{j=0}^{1} \kappa_{j} \Delta S M_{k, t-j}+ \\
& +\varpi \operatorname{SIZE}_{i, t-1}+\varpi^{*} \operatorname{SIZE}_{i, t-1} * \operatorname{CRISIS}+\tau L I Q_{i, t-1}+\zeta C A P_{i, t-1}+\sum_{j=1}^{4} \phi_{j} S D+\varepsilon_{i, t}
\end{aligned}
$$

Interestingly, the log of total assets (SIZE) now has the expected negative impact on bank riskiness in the pre-crisis period, while the interaction with the dummy for the crisis period is positive and significant (see the sixth column of Table 5). The sign of the TGAP variable is still negative and significant, confirming the fact that if the interest rate is below the benchmark rate, banks do take more risks. In this more complete specification, however, if the short-term interest rate is 100 basis points below the rate given by the Taylor rule, the average probability for a bank to default increases by $0.4 \%$ after a quarter, which is significantly lower than the baseline estimation ( $0.6 \%$ in the first column of Table 5$)$.

Historically, most systemic banking crises have been preceded by periods of excessive lending growth (Borio and Drehmann, 2009). Therefore, it would be interesting to test whether the risk-taking channel continues to work at the level of individual banks, even when controlling for the effect on banking risk due to excessive lending, which is more systemic in nature. We have, therefore, computed a bank-specific measure for excessive 
credit expansion by subtracting from the individual bank lending growth at a given point in time the mean of the growth for all the other banks over that specific quarter. Since the impact of excessive credit expansion on bank risk could be non-linear (see Section 3), the quadratic term was also added. ${ }^{11}$

$$
\begin{aligned}
\Delta E D F_{i, t}= & \alpha \Delta E D F_{i, t-1}+\sum_{j=0}^{1} \beta_{j} \Delta M P_{k, t-j}+\sum_{j=0}^{1} \gamma_{j} T G A P_{k, t-j}+\sum_{j=0}^{1} \delta_{j} \Delta G D P N_{k, t-j}+ \\
& +\sum_{j=0}^{1} \varphi_{j} S L O P E_{k, t-j}+\sum_{j=0}^{1} \mu_{j} \Delta H P_{k, t-j}+\sum_{j=0}^{1} \kappa_{j} \Delta S M_{k, t-j}+ \\
& +\varpi S I Z E_{i, t-1}+\tau L I Q_{i, t-1}+\zeta C A P_{i, t-1}+ \\
& +\theta_{1} \operatorname{EXLEND}_{i, t-1}+\theta_{2} \operatorname{EXLEND}_{i, t-1}^{2}+\sum_{j=1}^{4} \phi_{j} S D+\varepsilon_{i, t}
\end{aligned}
$$

The results reported in the last column of Table 5 show a U-shaped relationship between the deviation of lending growth from the mean value and bank risk. Banks that have a very low growth rate (that probably do not reach economies of scale), as well as those that have a high one (that may have a very aggressive price policy and supply a risky segment of the market), are considerably riskier than average (see Chart 3$){ }^{12}$ The sign of the TGAP variable, which monitors the risk-taking channel, remains negative and significant. The levels of the coefficients are predictably lower, because they capture only the part of the risk-taking channel that is dependent on non-traditional bank activities such as investment banking, securitization, derivatives and negotiation activity. The fact that a substantial part of the risk in bank balance sheets was not linked to traditional lending is amply documented (see, for instance, Shin, 2009).

\section{Different measures for bank risk}

The robustness of the results has been checked by considering a more complete term structure for bank risk. The reason for this test is that the one-year horizon for the EDF may

\footnotetext{
${ }^{11}$ See Kwan and Eisenbeis (1997).

12 The result still holds if we consider a bank-specific measure for excessive lending lagged 4 quarters instead of one quarter under the hypothesis that the market needs at least one year to detect a significant deviation of the credit portfolio of a given bank with respect to the industry average (Jiménez and Saurina, 2006). Similar results are obtained using the loan to total asset ratio instead than the lending growth rate. Estimations are available from the authors upon request.
} 
not be sufficient to capture certain properties of risk that build up over a longer time frame. In order to address this, equation (1) was rerun using the $E D F$ as a dependent variable with horizons of both five and ten years. Unfortunately, these data have only been officially available since 2004, thereby reducing the number of observations in the sample. Despite this, the results presented in the second and third columns of Table 6 are consistent with those for the baseline model that uses the $E D F$ over a one-year horizon (reported again for convenience in the first column of Table 6).

It is worth noticing that the increase of the $E D F$ horizon does not change the sign and the significance of the coefficients attached to the monetary policy indicator $(\triangle M P)$ or the Taylor Rule Gap (TGAP). It does, however, produce some effects on the absolute value of the $\beta$ and $\gamma$ coefficients. In particular, a drop in the monetary policy rate still reduces a bank's EDF by lowering the credit risk on outstanding loans, although the magnitude of this effect is reduced for a longer-term horizon, probably because a substantial number of credit positions opened today will be closed at a future date. On the contrary, the effectiveness of the risk-taking channel increases because it probably takes some time for banks to adjust their portfolios towards a more risky composition. Very similar results are obtained using the natural interest rate gap or other specifications of the Taylor rule as measures of accommodative monetary policy.

The second robustness test consists of calculating the impact of monetary policy on the idiosyncratic component of bank risk. In particular, it is necessary to test whether monetary policy influences an individual bank's attitude toward risk, independently of the developments of the banking system as a whole, a common driver for all intermediaries. In other words, we recognize that the banking sector is a highly interlinked industry subject to systemic shocks, which could operate regardless of individual bank risk attitude. With this in mind, our goal is to capture only individual bank risk, independent of developments in the banking market as a whole. In order to tease out systemic risk and obtain the idiosyncratic component of bank risk, two approaches, based on stock market information, were used: first, a simple CAPM model; second, the approach used by Campbell et al. (2001), who separate stock market risk into broad index, industrial sector and idiosyncratic components (see Section 3 for more details). The results for the baseline equation (1), when the two alternative measures for idiosyncratic risk are used, are reported in columns IV and V of 
Table 6. The use of idiosyncratic measures for bank risk does not change the sign and the significance of the monetary policy indicator $(\triangle M P)$ and the Taylor Rule Gap (TGAP). This confirms that bank risk-taking is not completely due to common factors emerging from the banking sector.

The third robustness test is the use of spreads on the credit default swap as an alternative variable for bank risk positions. This measure, which accounts for the cost of buying credit risk insurance subject to a certain credit event (usually a default), has been widely used during the recent credit crisis as the barometer of financial health and an early indicator of banks' problems (Blanco et al, 2005; Longstaff et al, 2005). Results for an unbalanced sample of more than 100 large banks over the period 2002-2009 obtained from Bloomberg were also consistent with those obtained by using the $E D F$ and idiosyncratic measure of banks risk. Results are not reported for the sake of brevity.

The fourth robustness test was to use changes in bank ratings as a dependent variable, in order to see whether our results hold when these ratings are considered as a proxy for bank risk. This test is interesting because downgrades in ratings are sluggish and take a long time to occur. This, for example, seems to have been the case for the rating of securitized products during the recent credit crisis (Benmelech and Dlugosz, 2009). The robustness test, therefore, used the banks' standard long-term senior unsecured rating history and ratings outlook, calculated by Moody's and available for a sub-sample of 149 banks, as a dependent variable in equation (1). In this case, the effect of the risk-taking channel is not strongly detected (i.e. the coefficients associated with $\triangle M P$ and the TGAP measure have the correct sign, but are no longer always significant). This could be due to the implementation of ratings downgrades, as observed during the Asian crisis (Ferri et al., 1999).

\section{Testing for non-linear effects, business expectations and regulatory differences}

The recent crisis has reminded us of the fact that the manifestation of risk may be sudden and not linear. This section, therefore, provides a number of tests to verify whether the risk-taking channel is still in place when specific non-linear interactions between monetary policy and bank risk are taken into account. 
The first aspect to consider is that the effect of monetary policy on bank risk may be influenced not only by the TGAP but also by two other aspects: firstly, the nominal level of the interest rate; secondly, how many consecutive quarters the interest rate has been below the benchmark. The baseline equation has, therefore, been modified to include terms that represent the interaction between the TGAP variable and, respectively, the level of the interest rate $(M P)$ and the number of consecutive quarters the interest rate has been below the level implied by the Taylor rule $(B E L)$.

$$
\begin{aligned}
& \Delta E D F_{i, t}=\alpha \Delta E D F_{i, t-1}+\sum_{j=0}^{1} \beta_{j} \Delta M P_{k, t-j}+\sum_{j=0}^{1} \gamma_{j} T G A P_{k, t-j}+\sum_{j=0}^{1} \delta_{j} \Delta G D P N_{k, t-j}+ \\
& \sum_{j=0}^{1} \varphi_{j} S L O P E_{k, t-j}+\sum_{j=0}^{1} \psi_{j} T G A P_{k, t-j} M P_{k, t-j}+\sum_{j=0}^{1} \rho_{j} T G A P_{k, t-j} B E L_{k, t-j}+\sum_{j=1}^{4} \phi_{j} S D+\varepsilon_{i, t}
\end{aligned}
$$

The first column of Table 7 shows that the negative link between $\triangle E D F$ and TGAP is reinforced if the level of interest is particularly low $\left(\psi_{j}>0\right)$, in line with the search for yield hypothesis. Financial intermediaries typically commit themselves to producing relatively high nominal rates of return in the long term. When interest rates become unusually low, independently of their relative distance with respect to the Taylor rule, the contractual returns can become more difficult to achieve and this can put pressure on banks to take on more risk in the hope of generating the return needed to remain profitable. Moreover, the coefficient $\rho_{j}$ is negative, confirming that the effects of monetary policy on bank risk are amplified in the case of an extended period of low interest rate. To sum up, it is not only the size of the deviation of the interest rate with respect to a benchmark that matters but also the length of time this deviation persists.

How can we be sure that what we are capturing are the effects of a risk-taking channel rather than heightened expectations of the economic conditions? Banks could indeed take on more risk simply because they anticipate better prospects rather than because interest rates are low. In order to control for this effect, we have included forward values of nominal growth in GDP, derived from Consensus Forecast Indicators $(\triangle G D P C F) .{ }^{13}$ The results reported in the second column of Table 7 show that the effects on bank risk of a long period of low interest rates are still in place.

\footnotetext{
${ }^{13}$ We thank Steven Cecchetti for this useful suggestion.
} 
Similar results are obtained when we also include into the specification the State Street Investor Confidence Index (SSICI), a measure of global investors' attitude to risk (see the third column of Table 7). The variable SSICI controls for elements of irrationality or other behavioral attitudes, such as herding behavior (Barberias et al., 1998; Brunnermeier and Nagel, 2004). ${ }^{14}$

The above results may be also influenced by differences in the intensity of bank supervision, which could have had an impact on the amount of risk undertaken (Beltratti and Stulz, 2009). In particular, it is necessary to verify whether more permissive legislation on bank activities could have led financial intermediaries to take more risks. Following the approach in Barth et al. (2004), a regulation variable (REG) has, therefore, been introduced into the baseline equation. This variable takes into account the extent to which banks may engage in securities, insurance and real estate activities. For the countries analyzed in this study, the variable $R E G$ takes a value from 5 to 12 , where the latter value represents the maximum level of activity in which banks may engage. The results in the fourth column of Table 7 indicate a positive and significant value for this variable, supporting the idea that banks took more risk in those countries where specific institutional factors allowed them to be involved in more non-traditional banking activities. Also, in this case, the coefficients for the monetary policy indicator $(\triangle M P)$, Taylor Rule Gap $(T G A P)$, and their interactions with $M P$ and $B E L$ remain basically unchanged, pointing to the fact that the effects of longstanding low interest rates on bank risk are still at work. Very similar results are obtained replacing the variable REG with a complete set of country dummies to take into account other institutional characteristics.

The effects of low interest rates on risk attitude may be influenced by bank specific characteristics. In order to detect heterogeneity in the link between low interest rates and bank risk, the baseline equation (1) has been enriched with bank specific characteristics (size, liquidity and capitalization) and their interactions with $T G A P$. In order to take into

\footnotetext{
${ }^{14}$ The State Street Investor Confidence Index focuses on expectations for future prices and returns and provides a quantitative measure of the actual and changing levels of risk contained in investment portfolios representing about $15 \%$ of the world's tradable assets. Further information is available at: http://www.statestreet.com/industry_insights/investor_confidence_index/ici_overview.html.
} 
account the fact that the effect of size has changed during the period of financial crisis, the triple interaction: $S I Z E_{i, t-1} * T G A P_{k, t-1} *$ CRISIS has also been inserted.

$$
\begin{aligned}
& \Delta E D F_{i, t}=\alpha \Delta E D F_{i, t-1}+\sum_{j=0}^{1} \beta_{j} \Delta M P_{k, t-j}+\sum_{j=0}^{1} \gamma_{j} T G A P_{k, t-j}+\sum_{j=0}^{1} \delta_{j} \Delta G D P N_{k, t-j}+\sum_{j=0}^{1} \varphi_{j} S L O P E_{k, t-j}+ \\
& +\varpi S I Z E_{i, t-1}+\tau L I Q_{i, t-1}+\zeta C A P_{i, t-1}+\varpi_{1} \operatorname{SIZE}_{i, t-1} * T G A P_{k, t-1}+\tau_{1} L I Q_{i, t-1} * T G A P_{k, t-1}+\sum_{j=0}^{1} \mu_{j} \Delta H P_{k, t-j}+ \\
& +\sum_{j=0}^{1} \kappa_{j} \Delta S M_{k, t-j}+\zeta_{1} C A P_{i, t-1} * T G A P_{k, t-1}+\varpi_{2} \operatorname{SIZE}_{i, t-1} * T G A P_{k, t-1} * C R I S I S+\sum_{j=1}^{4} \phi_{j} S D+\varepsilon_{i, t}
\end{aligned}
$$

The results in the last column of Table 7 show that the risk-taking channel is much stronger for low capitalized banks. Even in this case, the effect of bank size is different for the two sub-periods: small banks take on more risk prior to the crisis, while the effect is not significant during the crisis $\left(\varpi_{1}+\varpi_{2} \approx 0\right)$, when large banks encountered systemic problems.

\section{Modeling the probability of banks becoming risky}

In this section, the probability of a bank becoming risky during the crisis is modeled. In particular, those financial intermediaries that experienced the highest increase in their default probability after the 2007 summer are considered as risky. We have, therefore, created a binary variable (risky) that takes the value of 1 if the bank is in the last quartile of the distribution in terms of changes in the expected default probability in the period of financial crisis (2007Q2 - 2008Q4), and 0 elsewhere. Starting from a sample of 588 banks, whose median increase in default probability during the crisis was $0.7 \%$, banks considered as risky are those for which the increase was higher than $2.1 \%$ that delimit the last quarter of the distribution.

The probability of a bank becoming risky during the crisis is considered as a function of a combination of factors that developed prior to the crisis. On the one hand, this probability is determined by macro factors, such as the health of the economy, the evolution of asset prices, the level of interest rates and the structure of the yield curve; on the other hand, it is affected by bank specific characteristics, such as size, liquidity, capitalization, the use of securitization instruments, lending activity.

The baseline empirical model is given by the following probit equation: 


$$
P\left[\text { risky }_{i k}=1 \mid X\right]=\Phi\left(X^{\prime} \beta\right)
$$

where $P$ is the probability, $\Phi$ is the standard cumulative normal probability distribution, $X$ is a vector of regressors that include macro-variables of country $k$ where bank $i$ has its main seat and specific characteristics of the same bank $i$ over the five years prior to the crisis (2002 Q2 - 2007 Q2). As usual, $\beta$ parameters are estimated by maximum likelihood.

Table 8 summarizes the results of the estimation. The pseudo- $\mathrm{R}^{2}$ of the regression model, as in similar exercises, is not very high (14\%) and reflects the fact that the probit model only captures some of the underlying long-term causes of the financial turmoil and does not use any information from the crisis period. This means that the model neglects all those factors such as expectations of negative changes, difficulties in financial markets, liquidity interventions and, most importantly, bank idiosyncratic shocks that unfolded after the summer of 2007.

Consistently with the risk-taking channel hypothesis, the coefficient for the $B E L$ variable is positive and significant. This result confirms that if the interest rate is well below the benchmark rate for an overly extended period of time, banks do take more risks. ${ }^{15}$

The probit analysis aimed to take into consideration two additional factors, not analyzed so far, that could have influenced the evolution of bank risk prior to the crisis, namely, securitization activity and bank profitability.

The trigger of the crisis was the subprime mortgage segment in the US that highlighted the limitations of the Originate-to-Distribute (OTD) model. This means that it is interesting to check if the effectiveness of the risk-taking channel still holds controlling for the fact that most of the banks in the sample have relied heavily on the securitization market and might have simply reduced monitoring and screening on their loan portfolios (Parlour and Plantin, 2007). Drucker and Puri (2007) show that securitized loans tend to be less informationally sensitive than loans held by banks, i.e. banks sell loans such as mortgages for which screening and monitoring are less important than for commercial and industrial loans. In the specification, we included, therefore, a bank-specific ratio of securitization activity to assess

\footnotetext{
${ }^{15}$ Similar results are obtained using a LOGIT model or a simple $O L S$ where the dependent variable is simply the change in the bank EDF over the crisis period. Estimations are available from the authors upon request.
} 
whether banks that were more active in the securitization market experienced a higher increase in their default probability during the crisis. The results show that banks that securitized increased their default probability during the period of crisis, even if this effect is only marginally significant.

Profitability could have also played a role in bank risk-taking. It could be argued that certain banks which have done exceptionally well and achieved higher levels of profits prior to the crisis could be those who took the highest amounts of risk, for example, by expanding into segments of business with higher volatility of cash flows or by lowering their credit standards. Alternatively Berger et al. (2000) and Goddard et al. (2004) find evidence that there is significant year-to-year persistence in the profitability of US and European banks. To control for the possible impact of performance on bank risk, we have also included the average return on assets (ROA) as a measure of profitability. Unlike the return on equity, the return on total assets is a measure of banks' profits which does not include the influence on profits of leverage, which is already controlled by means of the capital-to-asset ratio.

There is also a long established literature arguing that increases in competition could lead to greater (and possibly excessive) risk-taking by banks. This is because increased competition reduces the market power of banks, thereby decreasing their charter value. The decline in charter value, coupled with the existence of limited liability and the application of flat rate deposit insurance, could encourage banks to take on more risk (Matutes and Vives, 2000). To take this into account, we have used the responses from the Bank Lending Survey for euro area banks and Senior Loan Officer Survey for US banks regarding the effect of competition on credit conditions to construct a net percentage index. This index, representing the number of banks that reported a tightening in credit conditions due to competition and the number that reported an easing, was used in the regression. The results indicate a positive link between the competition index (COMP) and risk-taking, but with no statistical significance. This result is in line with Boyd and De Niccoló (2005), who argue that the theoretical basis for linking more competition with increased incentives towards bank risk-taking is fragile. ${ }^{16}$

\footnotetext{
${ }^{16}$ See Carletti and Hartmann (2002) for a useful survey of the literature linking competition and stability.
} 


\section{Conclusions}

The current credit crisis has drawn the attention of researchers and policy makers back to the link between monetary policy and bank risk-taking. Low interest rates may influence banks' perceptions of, and attitude towards, risk in at least two ways: (i) through their impact on valuations, incomes and cash flows which in turn can modify how banks measure risk; (ii) through a more intensive search for yield process, especially when nominal return targets are in place. These two ways may be amplified if agents perceive that monetary policy will be relaxed in the case of decreasing asset prices in a financial downturn (the so-called insurance effect) causing a classic moral hazard problem.

The economic expansion that began in 2002 was characterized by the coexistence of low monetary policy rates, financial innovation and booming asset prices, three conditions that may have amplified the effectiveness of the risk-taking channel.

We contribute to the debate and analyze the link between monetary policy and bank risk using a comprehensive database of listed banks operating in 16 developed countries during and prior to the period of the financial crisis. We find that subdued low interest rates over an extended period of time contributed to an increase in banks' risk-taking. This central insight is of interest to both monetary and supervisory authorities and has two main corollaries. First, it suggests that central banks would need to be aware of the possible effects of their policies on banks' incentives. As a result monetary authorities would probably need to coordinate more intensively with macro prudential supervisors. Second, banking supervisors should be especially vigilant during periods of unusually low interest rates, particularly if accompanied by other signs of risk-taking, such as rapid credit and asset price increases. 
Tables and charts 
Table 1

\section{CORRELATION MATRIX}

\begin{tabular}{|c|c|c|c|c|c|c|c|c|c|c|c|c|c|c|c|c|c|c|c|c|c|}
\hline & $E D F$ & $E D F 5$ & EDF10 & $\operatorname{IDSC1}(2)$ & $\operatorname{IDSC2}(3)$ & LNRATE & $\triangle M P$ & $T G A P$ & TGAP2 & NRGAP & $\triangle G D P N$ & SLOPE & $\triangle H P$ & $\Delta S M$ & SIZE & $L I Q$ & $C A P$ & EXLEN & BELOW & $R E G$ & SSICI \\
\hline$E D F$ & 1.000 & & & & & & & & & & & & & & & & & & & & \\
\hline EDF5 & $\begin{array}{l}0.968 \\
0.000\end{array}$ & 1.000 & & & & & & & & & & & & & & & & & & & \\
\hline EDF10 & $\begin{array}{l}0.850 \\
0.000\end{array}$ & $\begin{array}{l}0.930 \\
0.000\end{array}$ & 1.000 & & & & & & & & & & & & & & & & & & \\
\hline IDSC1 (2) & $\begin{array}{l}0.089 \\
0.000\end{array}$ & $\begin{array}{l}0.084 \\
0.000\end{array}$ & $\begin{array}{l}0.092 \\
0.000\end{array}$ & 1.000 & & & & & & & & & & & & & & & & & \\
\hline $\operatorname{IDSC2}(3)$ & $\begin{array}{l}0.506 \\
0.000\end{array}$ & $\begin{array}{l}0.347 \\
0.000\end{array}$ & $\begin{array}{l}0.216 \\
0.000\end{array}$ & $\begin{array}{l}0.030 \\
0.000\end{array}$ & 1.000 & & & & & & & & & & & & & & & & \\
\hline LNRATE & $\begin{array}{l}0.166 \\
0.000\end{array}$ & $\begin{array}{l}0.196 \\
0.000\end{array}$ & $\begin{array}{l}0.247 \\
0.000\end{array}$ & $\begin{array}{l}0.070 \\
0.072\end{array}$ & $\begin{array}{l}0.079 \\
0.000\end{array}$ & 1.000 & & & & & & & & & & & & & & & \\
\hline$\triangle M P$ & $\begin{array}{l}-0.093 \\
0.000\end{array}$ & $\begin{array}{r}-0.220 \\
0.000\end{array}$ & $\begin{array}{r}-0.237 \\
0.000\end{array}$ & $\begin{array}{l}0.032 \\
0.000\end{array}$ & $\begin{array}{c}-0.032 \\
0.000\end{array}$ & $\begin{array}{c}-0.009 \\
0.551\end{array}$ & 1.000 & & & & & & & & & & & & & & \\
\hline TGAP & $\begin{array}{l}-0.098 \\
0.000\end{array}$ & $\begin{array}{l}-0.126 \\
0.000\end{array}$ & $\begin{array}{r}-0.266 \\
0.000\end{array}$ & $\begin{array}{l}0.091 \\
0.000\end{array}$ & $\begin{array}{r}-0.031 \\
0.000\end{array}$ & $\begin{array}{r}-0.066 \\
0.000\end{array}$ & $\begin{array}{l}0.459 \\
0.000\end{array}$ & 1.000 & & & & & & & & & & & & & \\
\hline TGAP2 & $\begin{array}{c}-0.203 \\
0.000\end{array}$ & $\begin{array}{r}-0.197 \\
0.000\end{array}$ & $\begin{array}{r}-0.259 \\
0.000\end{array}$ & $\begin{array}{l}0.024 \\
0.002\end{array}$ & $\begin{array}{r}-0.047 \\
0.000\end{array}$ & $\begin{array}{r}-0.047 \\
0.001\end{array}$ & $\begin{array}{l}0.248 \\
0.000\end{array}$ & $\begin{array}{l}0.627 \\
0.000\end{array}$ & 1.000 & & & & & & & & & & & & \\
\hline NRGAP & $\begin{array}{r}-0.183 \\
0.000\end{array}$ & $\begin{array}{r}-0.268 \\
0.000\end{array}$ & $\begin{array}{r}-0.310 \\
0.000\end{array}$ & $\begin{array}{l}0.035 \\
0.000\end{array}$ & $\begin{array}{r}-0.056 \\
0.000\end{array}$ & $\begin{array}{l}-0.020 \\
0.174\end{array}$ & $\begin{array}{l}0.408 \\
0.000\end{array}$ & $\begin{array}{l}0.708 \\
0.000\end{array}$ & $\begin{array}{l}0.857 \\
0.000\end{array}$ & 1.000 & & & & & & & & & & & \\
\hline$\triangle G D P N$ & $\begin{array}{c}-0.138 \\
0.000\end{array}$ & $\begin{array}{c}-0.272 \\
0.000\end{array}$ & $\begin{array}{c}-0.279 \\
0.000\end{array}$ & $\begin{array}{l}0.090 \\
0.000\end{array}$ & $\begin{array}{c}-0.017 \\
0.026\end{array}$ & $\begin{array}{l}-0.025 \\
0.083\end{array}$ & $\begin{array}{l}0.296 \\
0.000\end{array}$ & $\begin{array}{l}0.255 \\
0.000\end{array}$ & $\begin{array}{l}0.131 \\
0.000\end{array}$ & $\begin{array}{l}0.289 \\
0.000\end{array}$ & 1.000 & & & & & & & & & & \\
\hline SLOPE & $\begin{array}{l}0.024 \\
0.001\end{array}$ & $\begin{array}{l}0.160 \\
0.000 \\
0.000\end{array}$ & 0.131 & $\begin{array}{l}-0.011 \\
0.143\end{array}$ & $\begin{array}{l}0.005 \\
0.003\end{array}$ & $\begin{array}{l}0.010 \\
0.467\end{array}$ & $\begin{array}{l}-0.119 \\
0.000\end{array}$ & $\begin{array}{r}-0.342 \\
-0.000\end{array}$ & $\begin{array}{l}-0.0327 \\
-0.000\end{array}$ & $\begin{array}{l}-0.640 \\
-0.640\end{array}$ & $\begin{array}{l}-0.105 \\
-0.000\end{array}$ & 1.000 & & & & & & & & & \\
\hline$\triangle H P$ & $\begin{array}{l}0.001 \\
-0.155\end{array}$ & $\begin{array}{l}-0.352 \\
\end{array}$ & $\begin{array}{r}0.000 \\
-0.332\end{array}$ & $\begin{array}{l}0.143 \\
0.136\end{array}$ & $\begin{array}{l}0.503 \\
-0.096\end{array}$ & $\begin{array}{c}0.467 \\
-0.028\end{array}$ & $\begin{array}{l}0.000 \\
0.427\end{array}$ & $\begin{array}{l}0.000 \\
0.439\end{array}$ & $\begin{array}{l}0.000 \\
0.264\end{array}$ & $\begin{array}{l}0.000 \\
0.285\end{array}$ & $\begin{array}{l}0.000 \\
0.477\end{array}$ & -0.048 & 1.000 & & & & & & & & \\
\hline$\Delta S M_{t}$ & $\begin{array}{r}0.000 \\
-0.131\end{array}$ & $\begin{array}{c}0.000 \\
-0.345\end{array}$ & $\begin{array}{c}0.000 \\
-0.306\end{array}$ & $\begin{array}{l}0.000 \\
0.121 \\
0.000\end{array}$ & $\begin{array}{r}0.000 \\
-0.094 \\
0.090\end{array}$ & $\begin{array}{r}0.049 \\
-0.030 \\
\end{array}$ & $\begin{array}{l}0.000 \\
0.169\end{array}$ & $\begin{array}{l}0.000 \\
0.195 \\
0.000\end{array}$ & $\begin{array}{l}0.000 \\
0.186 \\
0.000\end{array}$ & $\begin{array}{l}0.000 \\
0.206 \\
0.000\end{array}$ & $\begin{array}{l}0.000 \\
0.375\end{array}$ & $\begin{array}{c}0.000 \\
-0.092\end{array}$ & 0.641 & 1.000 & & & & & & & \\
\hline SIZE & $\begin{array}{c}0.000 \\
-0.065\end{array}$ & $\begin{array}{c}0.000 \\
-0.069\end{array}$ & $\begin{array}{c}0.000 \\
-0.109\end{array}$ & $\begin{array}{c}0.000 \\
-0.522\end{array}$ & $\begin{array}{c}0.000 \\
-0.027\end{array}$ & $\begin{array}{c}0.038 \\
-0.498\end{array}$ & $\begin{array}{l}0.000 \\
0.013\end{array}$ & $\begin{array}{l}0.000 \\
0.042\end{array}$ & $\begin{array}{l}0.000 \\
0.054\end{array}$ & $\begin{array}{l}0.000 \\
0.045\end{array}$ & $\begin{array}{c}0.000 \\
-0.031\end{array}$ & $\begin{array}{c}0.000 \\
-0.042\end{array}$ & $\begin{array}{c}0.000 \\
-0.029\end{array}$ & -0.030 & 1.000 & & & & & & \\
\hline & 0.000 & 0.000 & 0.000 & 0.000 & 0.001 & 0.000 & 0.014 & 0.000 & 0.000 & 0.000 & 0.000 & 0.000 & 0.000 & 0.000 & & & & & & & \\
\hline LIQ & 0.003 & -0.080 & -0.045 & -0.077 & $\begin{array}{l}-0.016 \\
0.010\end{array}$ & -0.067 & 0.039 & 0.078 & 0.064 & 0.027 & 0.022 & 0.062 & 0.072 & 0.041 & 0.137 & 1.000 & & & & & \\
\hline CAP & $\begin{array}{c}0.646 \\
-0.024\end{array}$ & $\begin{array}{c}0.000 \\
-0.066\end{array}$ & $\begin{array}{c}0.000 \\
-0.113\end{array}$ & $\begin{array}{l}0.000 \\
0.113\end{array}$ & $\begin{array}{l}0.049 \\
-0.001\end{array}$ & $\begin{array}{l}0.000 \\
0.156\end{array}$ & $\begin{array}{l}0.000 \\
0.014\end{array}$ & $\begin{array}{l}0.000 \\
0.037\end{array}$ & $\begin{array}{l}0.000 \\
0.045\end{array}$ & $\begin{array}{l}0.000 \\
0.034\end{array}$ & $\begin{array}{c}0.000 \\
-0.016\end{array}$ & $\begin{array}{c}0.000 \\
-0.010\end{array}$ & $\begin{array}{l}0.000 \\
0.005\end{array}$ & $\begin{array}{c}0.000 \\
-0.001\end{array}$ & $\begin{array}{r}0.000 \\
-0.282\end{array}$ & 0.249 & 1.000 & & & & \\
\hline & 0.001 & 0.000 & 0.000 & 0.000 & 0.857 & 0.000 & 0.009 & 0.000 & 0.000 & 0.000 & 0.003 & 0.047 & 0.355 & 0.888 & 0.000 & 0.000 & & & & & \\
\hline EXLEND & $\begin{array}{r}-0.006 \\
0.383\end{array}$ & $\begin{array}{c}-0.022 \\
0.010\end{array}$ & $\begin{array}{r}-0.025 \\
0.001\end{array}$ & $\begin{array}{l}0.041 \\
0.000\end{array}$ & $\begin{array}{c}-0.001 \\
0.906\end{array}$ & $\begin{array}{l}-0.037 \\
0.019\end{array}$ & $\begin{array}{l}0.006 \\
0.309\end{array}$ & $\begin{array}{r}-0.016 \\
0.003\end{array}$ & $\begin{array}{c}-0.066 \\
0.000\end{array}$ & $\begin{array}{c}-0.042 \\
0.000\end{array}$ & $\begin{array}{l}0.000 \\
0.944\end{array}$ & $\begin{array}{c}-0.001 \\
0.808\end{array}$ & $\begin{array}{r}-0.030 \\
0.000\end{array}$ & $\begin{array}{l}0.002 \\
0.722\end{array}$ & $\begin{array}{r}-0.011 \\
0.046\end{array}$ & $\begin{array}{c}-0.033 \\
0.000\end{array}$ & $\begin{array}{c}-0.020 \\
0.000\end{array}$ & 1.000 & & & \\
\hline BELOW & 0.005 & 0.144 & 0.128 & -0.204 & 0.019 & 0.111 & -0.021 & -0.372 & -0.340 & -0.356 & -0.117 & 0.316 & -0.176 & -0.075 & $\begin{array}{l}-0.160 \\
-0.160\end{array}$ & -0.196 & -0.068 & 0.007 & 1.000 & & \\
\hline the & 0.447 & 0.000 & 0.000 & 0.000 & 0.015 & 0.000 & 0.000 & 0.000 & 0.000 & 0.000 & 0.000 & 0.000 & 0.000 & 0.000 & 0.000 & 0.000 & 0.000 & 0.191 & & & \\
\hline$R E G$ & 0.066 & 0.027 & 0.000 & 0.067 & 0.014 & 0.236 & -0.099 & -0.115 & -0.115 & -0.095 & 0.037 & -0.031 & 0.015 & -0.011 & -0.354 & -0.200 & -0.106 & 0.022 & 0.145 & 1.000 & \\
\hline Net & 0.000 & 0.002 & 0.998 & 0.000 & 0.061 & 0.000 & 0.000 & 0.000 & 0.000 & 0.000 & 0.000 & 0.000 & 0.001 & 0.014 & 0.000 & 0.000 & 0.000 & 0.000 & 0.000 & & \\
\hline SSICI & $\begin{array}{r}-0.034 \\
0.000\end{array}$ & $\begin{array}{r}-0.303 \\
0.000\end{array}$ & $\begin{array}{r}-0.228 \\
0.000\end{array}$ & $\begin{array}{l}0.241 \\
0.000\end{array}$ & $\begin{array}{r}-0.072 \\
0.000\end{array}$ & $\begin{array}{c}-0.078 \\
0.000\end{array}$ & $\begin{array}{l}0.009 \\
0.058\end{array}$ & $\begin{array}{l}0.248 \\
0.000\end{array}$ & $\begin{array}{l}0.214 \\
0.000\end{array}$ & $\begin{array}{l}0.176 \\
0.000\end{array}$ & $\begin{array}{l}0.304 \\
0.000\end{array}$ & $\begin{array}{l}0.001 \\
0.909\end{array}$ & $\begin{array}{l}0.320 \\
0.000\end{array}$ & $\begin{array}{l}0.262 \\
0.000\end{array}$ & $\begin{array}{c}-0.052 \\
0.000\end{array}$ & $\begin{array}{l}0.113 \\
0.000\end{array}$ & $\begin{array}{c}-0.010 \\
0.060\end{array}$ & $\begin{array}{l}0.000 \\
1.000\end{array}$ & $\begin{array}{c}-0.696 \\
0.000\end{array}$ & $\begin{array}{l}0.128 \\
0.000\end{array}$ & 1.000 \\
\hline
\end{tabular}


Table 2

\section{DESCRIPTIVE STATISTICS BY COUNTRY: 1999-2009}

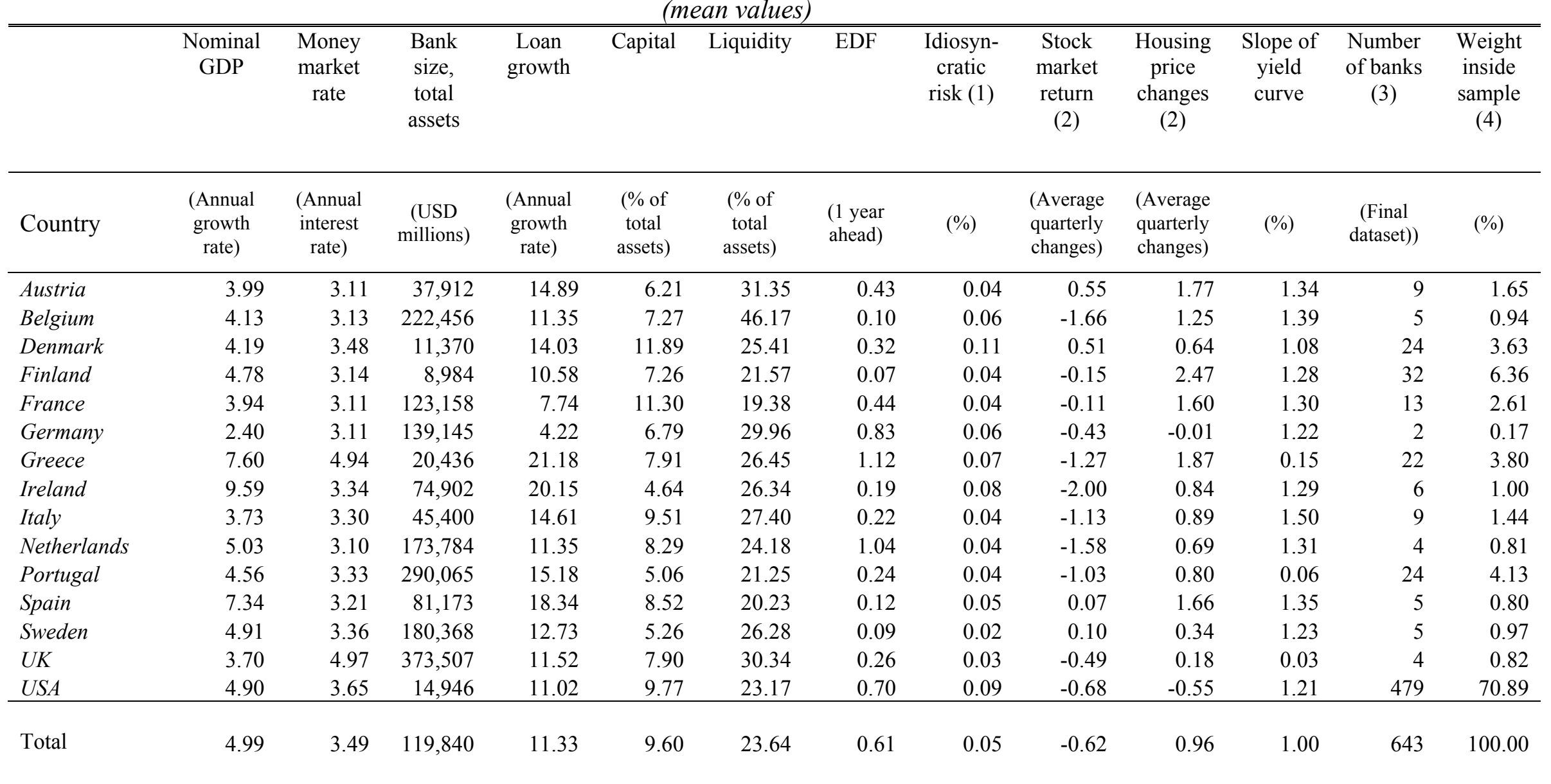

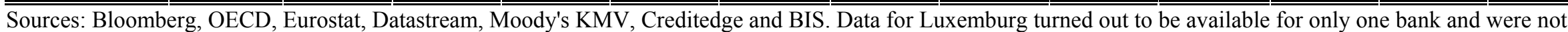
used for confidentiality reasons.

Notes: (1) Idiosyncratic risk is calculated following the estimation suggested by Campbell et al. (2001). For more details, see Appendix. (2) Adjusted for inflation. (3)

Banks analyzed in this table refer to the final dataset after the filtering process and other corrections. (4) As a percentage of the number of observations. 
Table 3

BALANCE SHEET CHARACTERISTICS AND BANK RISK PROFILE ${ }^{(1)}$

\begin{tabular}{|c|c|c|c|c|}
\hline $\begin{array}{l}\text { Distribution by bank } \\
\text { risk (one year ahead } \\
\text { EDF) }\end{array}$ & Size & Liquidity & Capitalization & Lending \\
\hline & (USD millions) & (\% total assets) & (\% total assets) & $\begin{array}{c}\text { (Annual growth } \\
\text { rate) }\end{array}$ \\
\hline $\begin{array}{l}\text { High-risk banks } \\
(E D F=2.02 \%)(a)\end{array}$ & 20,405 & 21.3 & 8.9 & 13.5 \\
\hline $\begin{array}{l}\text { Low-risk banks } \\
(E D F=0.09 \%)(b)\end{array}$ & 94,746 & 26.0 & 10.9 & 11.3 \\
\hline$\Delta=(a)-(b)$ & $-74,341$ & -4.7 & -2.0 & 2.2 \\
\hline
\end{tabular}


Table 4

\section{SUMMARY STATISTICS OF THE VARIABLES USED IN THE REGRESSIONS (1999 Q1-2008 Q4)}

\begin{tabular}{|c|c|c|c|c|c|c|c|c|}
\hline Variable & $\begin{array}{c}\text { Number of } \\
\text { observations }\end{array}$ & Mean & Median & Std. Dev & Min & Max & $\begin{array}{c}1 \mathrm{st} \\
\text { quartile }\end{array}$ & $\begin{array}{c}\text { 3rd } \\
\text { quartile }\end{array}$ \\
\hline$E D F_{t}$ & 19,796 & 0.61 & 0.17 & 1.9 & 0.01 & 29.98 & 0.08 & 0.43 \\
\hline$\Delta E D F_{t}$ & 19,796 & 0.07 & 0.00 & 0.83 & -28.0 & 27.0 & -0.03 & 0.03 \\
\hline$\Delta M P_{t}$ & 19,796 & -0.08 & 0.00 & 0.56 & -3.75 & 1.53 & -0.27 & 0.34 \\
\hline$\triangle T G A P_{t}$ & 19,796 & -0.44 & -0.27 & 0.57 & -3.6 & 1.37 & -0.76 & -0.07 \\
\hline$\triangle N R G A P_{t}$ & 19,796 & -0.3 & -0.21 & 1.41 & -5.1 & 3.62 & -1.1 & 0.63 \\
\hline$\triangle G D P N_{t}$ & 19,796 & 1.09 & 1.15 & 0.96 & -5.97 & 11.46 & 0.86 & 1.54 \\
\hline$\triangle S L O P E_{t}$ & 19,796 & 1.09 & 0.88 & 1.29 & -2.25 & 3.69 & -0.09 & 2.26 \\
\hline$\Delta H P_{t}$ & 19,796 & 0.00 & 0.84 & 4.95 & -22.98 & 79 & -1.45 & 2.52 \\
\hline$\Delta S M_{t}$ & 19,796 & 0.00 & 1.92 & 10.2 & -47.63 & 63.72 & -4.99 & 6.42 \\
\hline$S I Z E_{t}$ & 19,796 & 7.15 & 6.55 & 2.25 & -4.61 & 15.43 & 5.66 & 8.25 \\
\hline$L I Q_{t}$ & 19,796 & 23.62 & 22.61 & 10.7 & 0.00 & 49.99 & 15.72 & 30.54 \\
\hline$C A P_{t}$ & 19,796 & 9.6 & 8.75 & 5.03 & 1.03 & 74.90 & 6.99 & 10.89 \\
\hline$E X L E N D_{t}$ & 19,796 & 0.00 & -0.62 & 7.8 & -85.8 & 94.7 & -3.35 & 2.64 \\
\hline$E X L E N D_{t}^{2}$ & 19,796 & 60.00 & 9.12 & 290.2 & 0.00 & 8968.1 & 1.95 & 31.6 \\
\hline$B E L$ & 19,796 & 8.99 & 10.00 & 6.00 & 0.00 & 20.00 & 3.00 & 14.00 \\
\hline$R E G$ & 19,796 & 10.32 & 11.00 & 1.85 & 4.00 & 12.00 & 10.00 & 11.00 \\
\hline SSICI & 19,796 & 114.70 & 114.2 & 11.77 & 83.10 & 134.33 & 107.05 & 122.12 \\
\hline
\end{tabular}

where:

$\begin{array}{lll}E D F_{t} & = & \text { expected default frequency (1 year ahead) } \\ \triangle E D F_{t} & = & \text { change in the EDF (1 year ahead) } \\ \triangle M P_{t} & = & \text { changes in the money market rate } \\ \triangle T G A P_{t} & = & \text { changes in Taylor Rule gap } \\ \triangle N R G A P_{t} & = & \text { changes in natural interest rate gap } \\ \triangle G D P N_{t} & = & \text { changes in nominal GDP } \\ \triangle S L O P E_{t} & = & \text { changes in the slope of the yield curve } \\ \triangle H P_{t} & = & \text { quarterly changes in the housing price index (demeaned) } \\ \triangle S M_{t} & = & \text { quarterly changes in stock market returns (demeaned) } \\ S I Z E_{t} & = & \text { log of total assets (USD millions) } \\ L I Q_{t} & = & \text { liquidity-to-total assets } * 100 \\ C A P_{t} & = & \text { capital-to-total asset ratio } * 100 \\ E X L E N D_{t} & = & \text { excessive credit expansion (demeaned) } \\ E X L E N D_{t}{ }^{2} & = & \text { square term of excessive credit expansion (demeaned) } \\ B E L & = & \text { number of consecutive quarters with interest rate below the benchmark } \\ R E G & = & \text { regulatory index }\end{array}$


Table 5

REGRESSION RESULTS

\begin{tabular}{|c|c|c|c|c|c|c|c|c|c|c|c|c|c|c|}
\hline \multirow[t]{2}{*}{$\begin{array}{l}\text { Dependent variable: quarterly } \\
\text { change of the expected default } \\
\text { frequency (EDF) over a } 1 \text { year } \\
\text { horizon }\end{array}$} & \multicolumn{2}{|c|}{$\begin{array}{c}\text { (I) } \\
\text { Baseline model } \\
\text { (Taylor GAP) }\end{array}$} & \multicolumn{2}{|c|}{$\begin{array}{c}\text { (II) } \\
\text { Baseline model } \\
\text { (Natural rate GAP) }\end{array}$} & \multicolumn{2}{|c|}{$\begin{array}{c}\text { (III) } \\
\text { The financial accelerator } \\
\text { (house and stock market } \\
\text { returns) }\end{array}$} & \multicolumn{2}{|c|}{$\begin{array}{c}\text { (IV) } \\
\text { The financial accelerator } \\
\text { (different behaviour in } \\
\text { countries with boom-bust } \\
\text { housing cycle) }\end{array}$} & \multicolumn{2}{|c|}{$\begin{array}{c}\text { (V) } \\
\text { Bank specific } \\
\text { characteristics } \\
\text { (size, liquidity, } \\
\text { capitalization) }\end{array}$} & \multicolumn{2}{|c|}{\begin{tabular}{|c|} 
(VI) \\
Bank size effect during \\
the crisis
\end{tabular}} & \multicolumn{2}{|c|}{$\begin{array}{c}\text { (VII) } \\
\text { Excessive lending } \\
\text { expansion }\end{array}$} \\
\hline & Coeff. & S.Error & Coeff. & S.Error & Coeff. & S.Error & Coeff. & S.Error & Coeff. & S.Error & Coeff. & S.Error & Coeff. & S.Error \\
\hline$\Delta \mathrm{EDF}_{\mathrm{t}-1}$ & $0.222 * * *$ & 0.006 & $0.216 * * *$ & 0.006 & $0.223 * * *$ & 0.007 & $0.224 * * *$ & 0.007 & $0.302 * * *$ & 0.007 & $0.278 * * *$ & $0.007^{\prime}$ & $0.299 * * *$ & 0.008 \\
\hline $\begin{array}{l}\Delta M P_{\mathrm{t}} \\
\Delta \mathrm{M} P_{\mathrm{t}-1}\end{array}$ & $\begin{array}{l}0.114 * * \\
0.425 * * *\end{array}$ & $\begin{array}{l}0.050 \\
0.047\end{array}$ & $\begin{array}{l}0.064 * * \\
0.094 * * *\end{array}$ & $\begin{array}{l}0.030 \\
0.011\end{array}$ & $\begin{array}{l}0.185 * * * \\
0.344 * * *\end{array}$ & $\begin{array}{l}0.065 \\
0.051\end{array}$ & $\begin{array}{l}0.191 * * * \\
0.281 * * *\end{array}$ & $\begin{array}{l}0.069 \\
0.052\end{array}$ & $\begin{array}{l}0.080 * * \\
0.216 * * *\end{array}$ & $\begin{array}{l}0.041 \\
0.043\end{array}$ & $\begin{array}{l}0.082 * * * \\
0.185 * * *\end{array}$ & $\begin{array}{l}0.018 \\
0.027\end{array}$ & $\begin{array}{l}0.080 * * \\
0.148 * * *\end{array}$ & $\begin{array}{l}0.041 \\
0.033\end{array}$ \\
\hline $\begin{array}{l}T G A P_{\mathrm{t}} \\
T_{\mathrm{t}-1}\end{array}$ & $\begin{array}{l}-0.111 * * \\
-0.497 * * *\end{array}$ & $\begin{array}{l}0.050 \\
0.056\end{array}$ & & & $\begin{array}{l}-0.142 * * * \\
-0.447 * * *\end{array}$ & $\begin{array}{l}0.052 \\
0.060\end{array}$ & $\begin{array}{l}-0.185 * * * \\
-0.408 * * *\end{array}$ & $\begin{array}{l}0.055 \\
0.060\end{array}$ & $\begin{array}{l}-0.078 * \\
-0.262 * * *\end{array}$ & $\begin{array}{l}0.043 \\
0.046\end{array}$ & $\begin{array}{l}-0.202 * * * \\
-0.156 * * *\end{array}$ & $\begin{array}{l}0.028 \\
0.017\end{array}$ & $\begin{array}{l}-0.090 * * \\
-0.194 * * *\end{array}$ & $\begin{array}{l}0.036 \\
0.037\end{array}$ \\
\hline $\begin{array}{l}N R G A P_{\mathrm{t}} \\
N R G A P_{\mathrm{t}-1}\end{array}$ & & & $\begin{array}{l}-0.048 * * * \\
-0.111 * * *\end{array}$ & $\begin{array}{l}0.011 \\
0.013\end{array}$ & & & & & & & & & & \\
\hline $\begin{array}{l}\Delta \mathrm{GDPN}_{\mathrm{t}} \\
\Delta \mathrm{GDPN}_{\mathrm{t}-1}\end{array}$ & $\begin{array}{l}-0.095 * * * \\
-0.140 * * *\end{array}$ & $\begin{array}{l}0.013 \\
0.008\end{array}$ & $\begin{array}{l}-0.056 * * * \\
-0.111 * * *\end{array}$ & $\begin{array}{l}0.013 \\
0.008\end{array}$ & $\begin{array}{l}-0.106 * * * \\
-0.124 * * *\end{array}$ & $\begin{array}{l}0.014 \\
0.008\end{array}$ & $\begin{array}{l}-0.152 * * * \\
-0.158 * * *\end{array}$ & $\begin{array}{l}0.017 \\
0.008\end{array}$ & $\begin{array}{l}-0.080 * * * \\
-0.102 * * *\end{array}$ & $\begin{array}{l}0.010 \\
0.008\end{array}$ & $\begin{array}{l}-0.092 * * * \\
-0.112 * * *\end{array}$ & $\begin{array}{l}0.010 \\
0.007\end{array}$ & $\begin{array}{l}-0.101^{* * *} \\
-0.088^{* * *}\end{array}$ & $\begin{array}{l}0.009 \\
0.006\end{array}$ \\
\hline $\begin{array}{l}\mathrm{SLOPE}_{t} \\
\text { SLOPE }_{t-1}\end{array}$ & $\begin{array}{l}-0.011 * * \\
-0.068 * * *\end{array}$ & $\begin{array}{l}0.005 \\
0.020\end{array}$ & $\begin{array}{l}-0.021 * * \\
-0.099 * * *\end{array}$ & $\begin{array}{l}0.010 \\
0.021\end{array}$ & $\begin{array}{l}-0.027 * * \\
-0.084 * * *\end{array}$ & $\begin{array}{l}0.012 \\
0.023\end{array}$ & $\begin{array}{l}-0.019 * \\
-0.077 * * *\end{array}$ & $\begin{array}{l}0.010 \\
0.024\end{array}$ & $\begin{array}{l}-0.053 * * * \\
-0.050 * * *\end{array}$ & $\begin{array}{l}0.013 \\
0.011\end{array}$ & $\begin{array}{l}-0.030^{* *} \\
-0.031\end{array}$ & $\begin{array}{l}0.013 \\
0.011\end{array}$ & $\begin{array}{l}-0.054^{* * *} \\
-0.055^{* * *}\end{array}$ & $\begin{array}{l}0.010 \\
0.010\end{array}$ \\
\hline $\begin{array}{l}\Delta \mathrm{HP}_{\mathrm{t}} \\
\Delta \mathrm{HP}_{\mathrm{t}-1}\end{array}$ & & & & & $\begin{array}{l}0.010 * * * \\
0.002 *\end{array}$ & $\begin{array}{l}0.002 \\
0.001\end{array}$ & $\begin{array}{l}-0.004 * \\
-0.110 * * *\end{array}$ & $\begin{array}{l}0.002 \\
0.001\end{array}$ & $\begin{array}{l}0.011 * * * \\
0.002 *\end{array}$ & $\begin{array}{l}0.002 \\
0.001\end{array}$ & $\begin{array}{l}0.011 * * * \\
0.002 *\end{array}$ & $\begin{array}{l}0.002 \\
0.001\end{array}$ & $\begin{array}{l}0.010 * * * \\
0.002 *\end{array}$ & $\begin{array}{l}0.001 \\
0.001\end{array}$ \\
\hline $\begin{array}{l}\Delta \mathrm{SM}_{\mathrm{t}} \\
\Delta \mathrm{SM}_{\mathrm{t}-1}\end{array}$ & & & & & $\begin{array}{l}-0.010 * * * \\
-0.011 * * *\end{array}$ & $\begin{array}{l}0.001 \\
0.001\end{array}$ & $\begin{array}{l}-0.009 * * * \\
-0.007 * * *\end{array}$ & $\begin{array}{l}0.001 \\
0.001\end{array}$ & $\begin{array}{l}-0.011 * * * \\
-0.007 * * *\end{array}$ & $\begin{array}{l}0.001 \\
0.001\end{array}$ & $\begin{array}{l}-0.007 * * * \\
-0.004 * * *\end{array}$ & $\begin{array}{l}0.001 \\
0.001\end{array}$ & $\begin{array}{l}-0.010^{* * *} \\
-0.004 * * *\end{array}$ & $\begin{array}{l}0.001 \\
0.001\end{array}$ \\
\hline $\begin{array}{l}\Delta \mathrm{HP}_{\mathrm{t}} * \mathrm{HPBB} \\
\Delta \mathrm{HP}_{\mathrm{t}-1} * \mathrm{HPBB}\end{array}$ & & & & & & & $\begin{array}{l}0.016^{* * *} \\
0.014 * * *\end{array}$ & $\begin{array}{l}0.004 \\
0.004\end{array}$ & & & & & & \\
\hline $\begin{array}{l}\Delta \mathrm{SM}_{\mathrm{t}}^{*} \mathrm{HPBB} \\
\Delta \mathrm{SM}_{\mathrm{t}-1} * \mathrm{HPBBB}\end{array}$ & & & & & & & $\begin{array}{l}-0.004 * * * \\
-0.005 * * *\end{array}$ & $\begin{array}{l}0.001 \\
0.001\end{array}$ & & & & & & \\
\hline $\begin{array}{l}\operatorname{SIZE}_{t-1} \\
\text { LIQ }_{t-1} \\
\text { CAP }_{t-1}\end{array}$ & & & & & & & & & $\begin{array}{r}0.060 * * * \\
-0.008 * * * \\
-0.013 * * *\end{array}$ & $\begin{array}{l}0.009 \\
0.001 \\
0.001\end{array}$ & $\begin{array}{l}-0.033 * * * \\
-0.004 * * * \\
-0.016^{* * *}\end{array}$ & $\begin{array}{l}0.011 \\
0.001 \\
0.001\end{array}$ & $\begin{array}{r}0.039^{* * *} \\
-0.012 * * * \\
-0.019^{* * *}\end{array}$ & $\begin{array}{l}0.009 \\
0.001 \\
0.001\end{array}$ \\
\hline SIZE $_{\mathrm{t}-1 * \text { CRISIS }}$ & & & & & & & & & & & $0.030 * * *$ & 0.002 & & \\
\hline $\begin{array}{l}\text { LEND_GROWTH } \\
\text { LEND_GROWTH }_{t-1} \wedge 2\end{array}$ & & & & & & & & & & & & & $\begin{array}{l}0.0013 \\
0.0001 * * *\end{array}$ & $\begin{array}{l}0.003 \\
0.000\end{array}$ \\
\hline Sample period & \multicolumn{2}{|c|}{1999 Q1 - 2008 Q4 } & \multicolumn{2}{|c|}{1999 Q1 - 2008 Q4 } & \multicolumn{2}{|c|}{1999 Q1 - 2008 Q4 } & \multicolumn{2}{|c|}{1999 Q1 - 2008 Q4 } & \multicolumn{2}{|c|}{1999 Q1 - 2008 Q4 } & \multicolumn{2}{|c|}{1999 Q1 - 2008 Q4 } & \multicolumn{2}{|c|}{1999 Q1 - 2008 Q4 } \\
\hline $\begin{array}{l}\text { No ot banks, No of } \\
\text { observations } \\
\text { Sargan test (2nd step; pvalue) }\end{array}$ & 643 & $\begin{array}{r}19,796 \\
0.293\end{array}$ & 643 & $\begin{array}{r}19,796 \\
0.198\end{array}$ & 643 & $\begin{array}{r}19,796 \\
0.247\end{array}$ & 643 & $\begin{array}{r}19,796 \\
0.225\end{array}$ & 643 & $\begin{array}{r}19,796 \\
0.275\end{array}$ & 643 & $\begin{array}{r}19,796 \\
0.277\end{array}$ & 588 & $\begin{array}{r}18,303 \\
0.258\end{array}$ \\
\hline $\mathrm{MA}(1), \mathrm{MA}(2)$ (p-value) & 0.000 & 0.695 & 0.000 & 0.696 & 0.000 & 0.631 & 0.000 & 0.759 & 0.000 & 0.374 & 0.000 & 0.741 & 0.000 & 0.723 \\
\hline
\end{tabular}


Table 6

DIFFERENT MEASURES FOR BANK RISK

\begin{tabular}{|c|c|c|c|c|c|c|c|c|c|c|c|c|}
\hline \multirow[t]{2}{*}{$\begin{array}{l}\text { Different measures of bank risk } \\
\text { as dependent variable. }\end{array}$} & \multicolumn{2}{|c|}{$\Delta \mathrm{EDF} 1 \mathrm{yrs}$} & \multicolumn{2}{|c|}{ 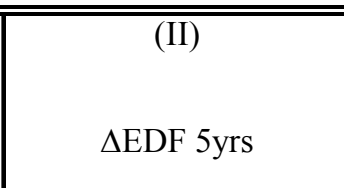 } & \multicolumn{2}{|c|}{ 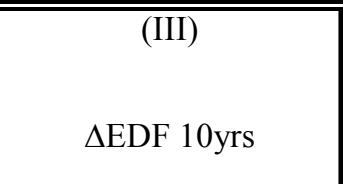 } & \multicolumn{2}{|c|}{$\begin{array}{c}\text { (IV) } \\
\text { Idiosyncratic measure } \\
\text { (CAPM model) }\end{array}$} & \multicolumn{2}{|c|}{\begin{tabular}{c|}
$(\mathrm{V})$ \\
\\
Idiosyncratic measure \\
(Campbell et al. 2001)
\end{tabular}} & \multicolumn{2}{|c|}{$\begin{array}{c}\text { (VI) } \\
\Delta \text { Rating }\end{array}$} \\
\hline & Coeff. & S.Error & Coeff. & S.Error & Coeff. & S.Error & Coeff. & S.Error & Coeff. & S.Error & Coeff. & S.Error \\
\hline Dependent variable $_{t-1}$ & $0.222 * * *$ & 0.006 & $0.310 * * *$ & 0.006 & $0.291 * * *$ & 0.000 & $0.481 * * *$ & 0.007 & $0.393 * * *$ & 0.020 & 0.001 & 0.011 \\
\hline$\Delta M P_{\mathrm{t}}$ & $0.114 * *$ & 0.050 & $0.276 * * *$ & 0.052 & $0.202 * * *$ & 0.069 & $0.034 * * *$ & 0.008 & $0.052 * * *$ & 0.009 & 0.002 & 0.002 \\
\hline$\Delta M P_{\mathrm{t}-1}$ & $0.425 * * *$ & 0.047 & $0.091 * * *$ & 0.023 & $0.089 *$ & 0.047 & $0.160 * * *$ & 0.007 & $0.155 * * *$ & 0.014 & $0.007 *$ & 0.004 \\
\hline$T G A P_{\mathrm{t}}$ & $-0.111 * *$ & 0.050 & $-0.176 * * *$ & 0.064 & $-0.684 * * *$ & 0.078 & $-0.027 * * *$ & 0.007 & $-0.185 * * *$ & 0.015 & $-0.007 * *$ & 0.003 \\
\hline$T G A P_{\mathrm{t}-1}$ & $-0.497 * * *$ & 0.056 & $-0.592 * * *$ & 0.094 & $-0.254 * *$ & 0.110 & $-0.028 * * *$ & 0.002 & $-0.077 * * *$ & 0.008 & -0.001 & 0.002 \\
\hline$\Delta \mathrm{GDPN}_{\mathrm{t}}$ & $-0.095 * * *$ & 0.013 & $-0.192 * * *$ & 0.029 & $-0.357 * * *$ & 0.035 & $-0.013 * * *$ & 0.001 & $-0.056 * * *$ & 0.004 & -0.001 & 0.001 \\
\hline$\Delta \mathrm{GDPN}_{\mathrm{t}-1}$ & $-0.140 * * *$ & 0.008 & $-0.206 * * *$ & 0.018 & $-0.331 * * *$ & 0.026 & $-0.012 * * *$ & 0.001 & $-0.080 * * *$ & 0.004 & -0.001 & 0.001 \\
\hline SLOPE $_{t}$ & $-0.011 * *$ & 0.005 & $-0.090 *$ & 0.047 & -0.092 & 0.058 & $-0.004 *$ & 0.002 & $-0.024 * * *$ & 0.009 & -0.001 & 0.002 \\
\hline $\mathrm{SLOPE}_{\mathrm{t}-1}$ & $-0.068 * * *$ & 0.020 & $-0.155 * * *$ & 0.050 & $-0.251 * * *$ & 0.054 & $-0.035 * * *$ & 0.002 & $-0.018 * *$ & 0.008 & -0.001 & 0.001 \\
\hline Sample period & \multicolumn{2}{|c|}{1999 Q1 - 2008 Q4 } & \multicolumn{2}{|c|}{2004 Q1 - 2008 Q4 } & \multicolumn{2}{|c|}{2004 Q1 - 2004 Q4 } & \multicolumn{2}{|c|}{1999 Q1 - 2008 Q4 } & \multicolumn{2}{|c|}{1999 Q1 - 2008 Q4 } & \multicolumn{2}{|c|}{1999 Q1 - 2008 Q4 } \\
\hline \multirow{3}{*}{$\begin{array}{l}\text { No. ot banks, no. of } \\
\text { observations } \\
\text { Sargan test (2nd step; pvalue) } \\
\text { MA(1), MA(2) (p-value) }\end{array}$} & 643 & 19,796 & 643 & 11,631 & 643 & 11,631 & 643 & 19,796 & 643 & 19,796 & 149 & 4,500 \\
\hline & & 0.211 & & 0.175 & & 0.222 & & 0.296 & & 0.211 & & 0.311 \\
\hline & 0.000 & 0.695 & 0.000 & 0.202 & 0.000 & 0.599 & 0.000 & 0.400 & 0.000 & 0.695 & 0.000 & 0.364 \\
\hline
\end{tabular}

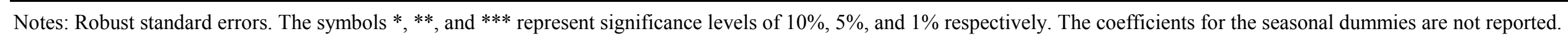

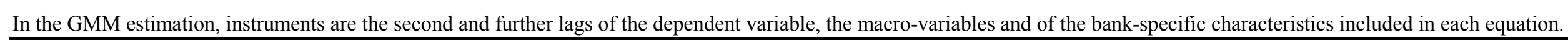


Table 7

TESTING FOR NON-LINEAR EFFECTS, BUSINESS EXPECTATIONS AND DIFFERENCES IN REGULATION

\begin{tabular}{|c|c|c|c|c|c|c|c|c|c|c|}
\hline \multirow[t]{2}{*}{$\begin{array}{l}\text { Dependent variable: quarterly } \\
\text { change of the expected default } \\
\text { frequency (EDF) over a } 1 \text { year } \\
\text { horizon }\end{array}$} & \multicolumn{2}{|c|}{$\begin{array}{c}\text { (I) } \\
\text { Controlling for } \\
\text { nominal level of } \\
\text { interest rates and } \\
\text { extended period of } \\
\text { low interest rates }\end{array}$} & \multicolumn{2}{|c|}{$\begin{array}{c}\text { (II) } \\
\text { Controlling for } \\
\text { changes in business } \\
\text { expectations } \\
\text { (Consensus Forecast) }\end{array}$} & \multicolumn{2}{|c|}{\begin{tabular}{|c|} 
(III) \\
Controlling for \\
changes in risk \\
appetite (State Street \\
Investor Confidence \\
Index)
\end{tabular}} & \multicolumn{2}{|c|}{\begin{tabular}{|c|} 
(IV) \\
Difference in \\
regulation (Barth et \\
al., 2004)
\end{tabular}} & \multicolumn{2}{|c|}{$\begin{array}{l}\text { (V) } \\
\text { Heterogeneity in the } \\
\text { risk-taking channels } \\
\text { among banks }\end{array}$} \\
\hline & Coeff. & S.Error & Coeff. & S.Error & Coeff. & S.Error & Coeff. & S.Error & Coeff. & S.Error \\
\hline$\Delta \mathrm{EDF}_{\mathrm{t}-1}$ & $0.203 * * *$ & 0.007 & $0.242 * * *$ & 0.008 & $0.244 * * *$ & 0.007 & $0.240 * * *$ & 0.007 & $0.325 * * *$ & 0.007 \\
\hline$\Delta M P_{\mathrm{t}}$ & 0.070 & 0.068 & $0.262 * * *$ & 0.052 & $0.263 * * *$ & 0.057 & $0.241 * * *$ & 0.052 & $0.200 * * *$ & 0.053 \\
\hline$\Delta M P_{\mathrm{t}-1}$ & $0.226 * * *$ & 0.054 & $0.125 * * *$ & 0.040 & $0.120 * * *$ & 0.044 & $0.142 * * *$ & 0.042 & $0.120 * * *$ & 0.044 \\
\hline$T G A P_{\mathrm{t}}$ & $-0.167 * *$ & 0.080 & $-0.322 * * *$ & 0.056 & $-0.318 * * *$ & 0.057 & $-0.146 * *$ & 0.058 & $-0.513 * * *$ & 0.117 \\
\hline$T G A P_{\mathrm{t}-1}$ & $-0.057 *$ & 0.030 & -0.093 & 0.057 & $-0.065 *$ & 0.037 & $-0.213 * * *$ & 0.078 & $-0.599 * * *$ & 0.047 \\
\hline$\Delta \mathrm{GDPN}_{\mathrm{t}}$ & $-0.017 * *$ & 0.008 & & & & & & & $-0.098 * * *$ & 0.011 \\
\hline$\Delta \mathrm{GDPN}_{\mathrm{t}-1}$ & $-0.114 * * *$ & 0.008 & & & & & & & $-0.092 * * *$ & 0.008 \\
\hline $\mathrm{SLOPE}_{\mathrm{t}}$ & $-0.043 *$ & 0.025 & -0.025 & 0.019 & $-0.031 *$ & 0.018 & -0.016 & 0.017 & $-0.080 * * *$ & 0.016 \\
\hline SLOPE $_{t-1}$ & $-0.081 * * *$ & 0.022 & $-0.042 * * *$ & 0.016 & $-0.042 * * *$ & 0.016 & $-0.080 * * *$ & 0.017 & $-0.060 * * *$ & 0.014 \\
\hline $\mathrm{TGAP}_{\mathrm{t}} * \mathrm{MP}_{\mathrm{t}}$ & $0.134 * * *$ & 0.017 & $0.025 * *$ & 0.011 & $0.025 * *$ & 0.011 & 0.011 & 0.011 & & \\
\hline $\mathrm{TGAP}_{\mathrm{t}-1} * \mathrm{MP}_{\mathrm{t}-1}$ & $0.024 *$ & 0.014 & $0.020 *$ & 0.012 & $0.020 *$ & 0.012 & $0.050 * * *$ & 0.012 & & \\
\hline $\mathrm{TGAP}_{\mathrm{t}} * \mathrm{BEL}_{\mathrm{t}}$ & $-0.015 * * *$ & 0.001 & $-0.005 * * *$ & 0.001 & $-0.005 * * *$ & 0.001 & $-0.009 * * *$ & 0.001 & & \\
\hline $\mathrm{TGAP}_{\mathrm{t}-1} * \mathrm{BEL}_{\mathrm{t}-1}$ & $-0.045 * * *$ & 0.002 & $-0.013 * * *$ & 0.002 & $-0.003 * *$ & 0.001 & $-0.003 *$ & 0.001 & & \\
\hline$\triangle \mathrm{GDPNCF}_{\mathrm{t}}$ & & & $-0.073 * * *$ & 0.008 & $-0.063 * * *$ & 0.008 & $-0.111 * * *$ & 0.008 & & \\
\hline$\Delta \mathrm{GDPNCF}_{\mathrm{t}+1}$ & & & $-0.011 *$ & 0.006 & $-0.010 *$ & 0.006 & 0.004 & 0.006 & & \\
\hline $\mathrm{SSICI}_{\mathrm{t}}$ & & & & & $0.002 *$ & 0.001 & & & & \\
\hline $\mathrm{REG}_{\mathrm{t}}$ & & & & & & & $0.119 * * *$ & 0.014 & & \\
\hline$\Delta \mathrm{HP}_{\mathrm{t}}$ & & & & & & & & & $0.016 * * *$ & 0.002 \\
\hline$\Delta \mathrm{HP}_{\mathrm{t}-1}$ & & & & & & & & & $0.005 * * *$ & 0.001 \\
\hline$\Delta \mathrm{SM}_{\mathrm{t}}$ & & & & & & & & & $-0.007 * * *$ & 0.001 \\
\hline$\Delta \mathrm{SM}_{\mathrm{t}-1}$ & & & & & & & & & $-0.005 * * *$ & 0.001 \\
\hline $\mathrm{SIZE}_{\mathrm{t}-1}$ & & & & & & & & & $0.023 * * *$ & 0.008 \\
\hline $\mathrm{LIQ}_{\mathrm{t}-1}$ & & & & & & & & & $-0.014 * * *$ & 0.002 \\
\hline $\mathrm{CAP}_{\mathrm{t}-1}$ & & & & & & & & & $-0.034 * * *$ & 0.004 \\
\hline $\mathrm{SIZE}_{\mathrm{t}-1} * \mathrm{TGAP}_{\mathrm{t}-1}$ & & & & & & & & & $0.084 * * *$ & 0.014 \\
\hline $\mathrm{LIQ}_{\mathrm{t}-1} * \mathrm{TGAP}_{\mathrm{t}-1}$ & & & & & & & & & 0.001 & 0.001 \\
\hline $\mathrm{CAP}_{\mathrm{t}-1} * \mathrm{TGAP}_{\mathrm{t}-1}$ & & & & & & & & & $0.021 * * *$ & 0.002 \\
\hline SIZE $_{t-1} *$ TGAP $_{t-1} *$ CRISIS & & & & & & & & & -0.025 & 0.003 \\
\hline Sample period & \multicolumn{2}{|c|}{1999 Q1 - 2008 Q4 } & \multicolumn{2}{|c|}{1999 Q1 - 2008 Q4 } & \multicolumn{2}{|c|}{1999 Q1 - 2008 Q4 } & \multicolumn{2}{|c|}{1999 Q1 - 2008 Q4 } & \multicolumn{2}{|c|}{1999 Q1 - 2008 Q4 } \\
\hline $\begin{array}{l}\text { No of banks, No of } \\
\text { observations }\end{array}$ & 643 & 19,796 & 643 & 19,796 & 643 & 19,796 & 643 & 19,796 & 643 & 19,796 \\
\hline Sargan test (2nd step; pvalue) & & 0.687 & & 0.825 & & 0.333 & & 0.261 & & 0.456 \\
\hline MA(1), MA(2) (p-value) & 0.000 & 0.849 & 0.000 & 0.871 & 0.000 & 0.863 & 0.000 & 0.928 & 0.000 & 0.700 \\
\hline
\end{tabular}

Notes: Robust standard errors. The symbols *, **, and *** represent significance levels of $10 \%, 5 \%$, and $1 \%$ respectively. The coefficients for the seasonal dummies are not reported.In the GMM estimation, instruments are the second and further lags of the dependent variable, the macro-variables and of the bank-specific characteristics included in each equation. 
Table 8

MODELLING THE PROBABILITY FOR A BANK TO BECOME RISKY

\begin{tabular}{|c|c|c|c|c|c|c|c|c|c|}
\hline \multirow{2}{*}{$\begin{array}{c}\text { Dependent } \\
\text { variable: } \\
\mathrm{P}\left(\text { risky }_{\mathrm{ik}}=1\right)\end{array}$} & \multicolumn{3}{|c|}{$\begin{array}{c}\text { (I) } \\
\text { Baseline equation }\end{array}$} & \multicolumn{3}{|c|}{$\begin{array}{c}\text { (II) } \\
\text { Bank profit }\end{array}$} & \multicolumn{3}{|c|}{$\begin{array}{c}\text { (III) } \\
\text { Competition effect }\end{array}$} \\
\hline & Coef. & Sig & $\begin{array}{l}\text { Robust } \\
\text { Std. Err. }\end{array}$ & Coef. & Sig & Coef. & Coef. & Sig & Coef. \\
\hline BEL & 0.285 & $* * *$ & 0.091 & $0.288=$ & $* * *$ & 0.094 & $0.321=$ & $* * *$ & 0.108 \\
\hline$\triangle \mathrm{GDPN}$ & -1.178 & $* *$ & 0.575 & -1.185 & $* *$ & 0.589 & -1.541 & $* *$ & 0.763 \\
\hline SLOPE & -1.277 & $* *$ & 0.517 & -1.317 & $* *$ & 0.531 & -1.726 & $* *$ & 0.748 \\
\hline$\Delta \mathrm{HP}$ & 0.836 & $* * *$ & 0.209 & 0.899 & $* * *$ & 0.217 & $1.239^{\circ}$ & $* * *$ & 0.458 \\
\hline$\Delta \mathrm{SM}$ & 0.758 & $* * *$ & 0.274 & 0.803 & $* * *$ & 0.283 & 0.879 & $* * *$ & 0.309 \\
\hline EDF & 0.276 & $* * *$ & 0.101 & 0.256 & $* *$ & 0.114 & $0.269=$ & $* *$ & 0.116 \\
\hline SIZE & -0.023 & & 0.038 & 0.001 & & 0.040 & 0.004 & & 0.040 \\
\hline LIQ & -0.012 & $* *$ & 0.005 & -0.013 & $* *$ & 0.005 & -0.013 & $* *$ & 0.005 \\
\hline CAP & -0.046 & $* * *$ & 0.017 & -0.033 & $*$ & 0.018 & -0.034 & $*$ & 0.018 \\
\hline SEC & 0.198 & $*$ & 0.113 & 0.196 & $*$ & 0.111 & $0.204=$ & & 0.115 \\
\hline EXLEND & 0.146 & $* * *$ & 0.025 & 0.157 & $* * *$ & 0.026 & $0.158=$ & $* * *$ & 0.026 \\
\hline REG & 0.064 & & 0.103 & 0.088 & & 0.105 & 0.056 & & 0.109 \\
\hline ROA & & & & -0.270 & $* *$ & 0.126 & -0.279 & $* *$ & 0.127 \\
\hline COMP & & & & & & & 0.041 & & 0.046 \\
\hline constant & -5.947 & $* * *$ & 2.004 & -6.499 & $* * *$ & 2.078 & -7.122 & $* * *$ & 2.256 \\
\hline Number of obs & & 588 & & & 588 & & & 588 & \\
\hline LR $\operatorname{chi}^{2}(14)$ & & 94.32 & & & 96.86 & & & 97.66 & \\
\hline Prob $>\mathrm{chi}^{2}$ & & 0.000 & & & 0.000 & & & 0.000 & \\
\hline Pseudo $\mathrm{R}^{2}$ & & 0.1417 & & & 0.1476 & & & 0.1488 & \\
\hline
\end{tabular}


EXPECTED DEFAULT FREQUENCY OF BANKS

Chart 1

(over a 1 year ahead horizon; averages by country and groups of countries)

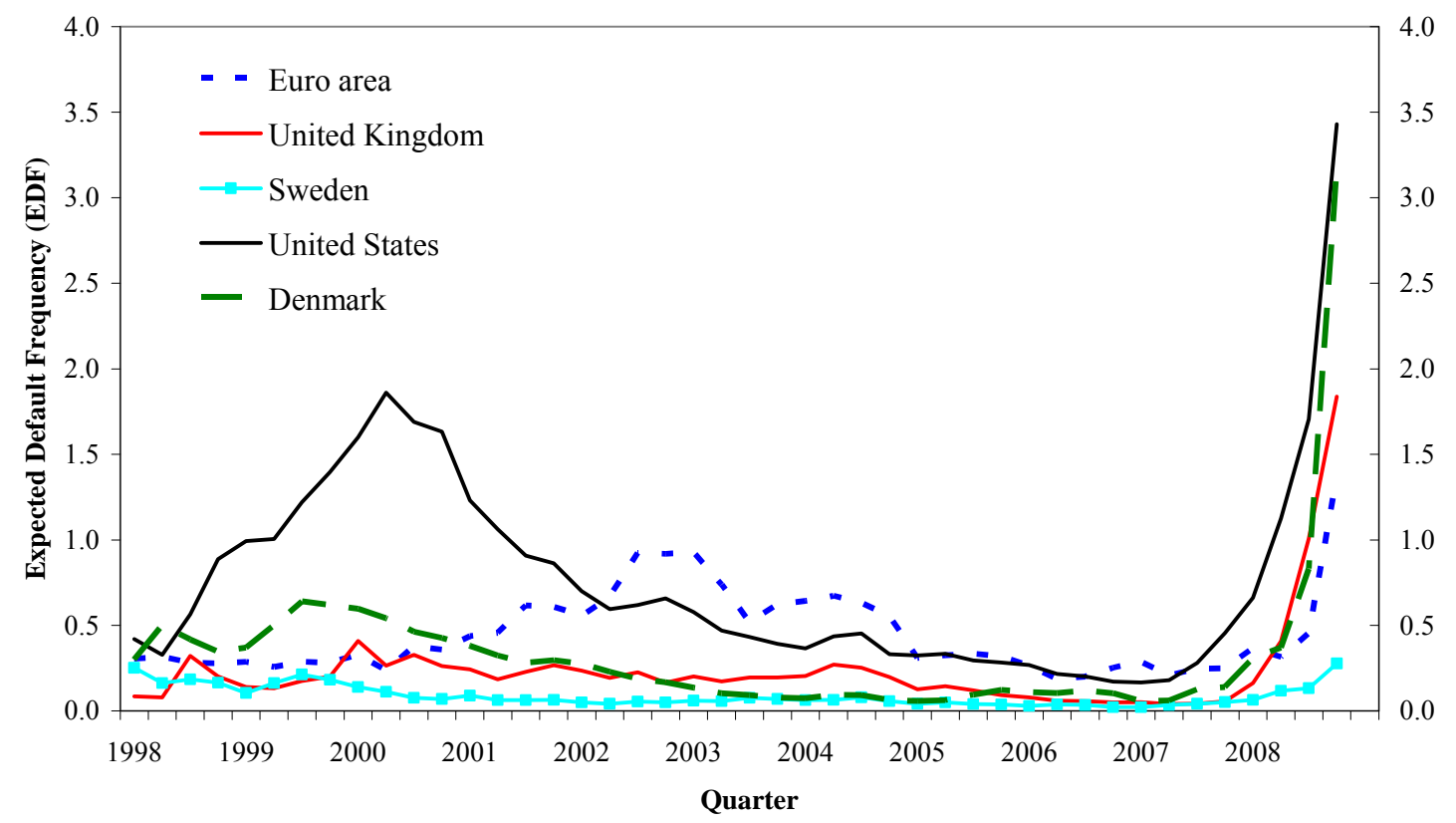

Source: Moody's KMV.

Chart 2

ALTERNATIVE MEASURES TO EVALUATE MONETARY POLICY STANCE

United States

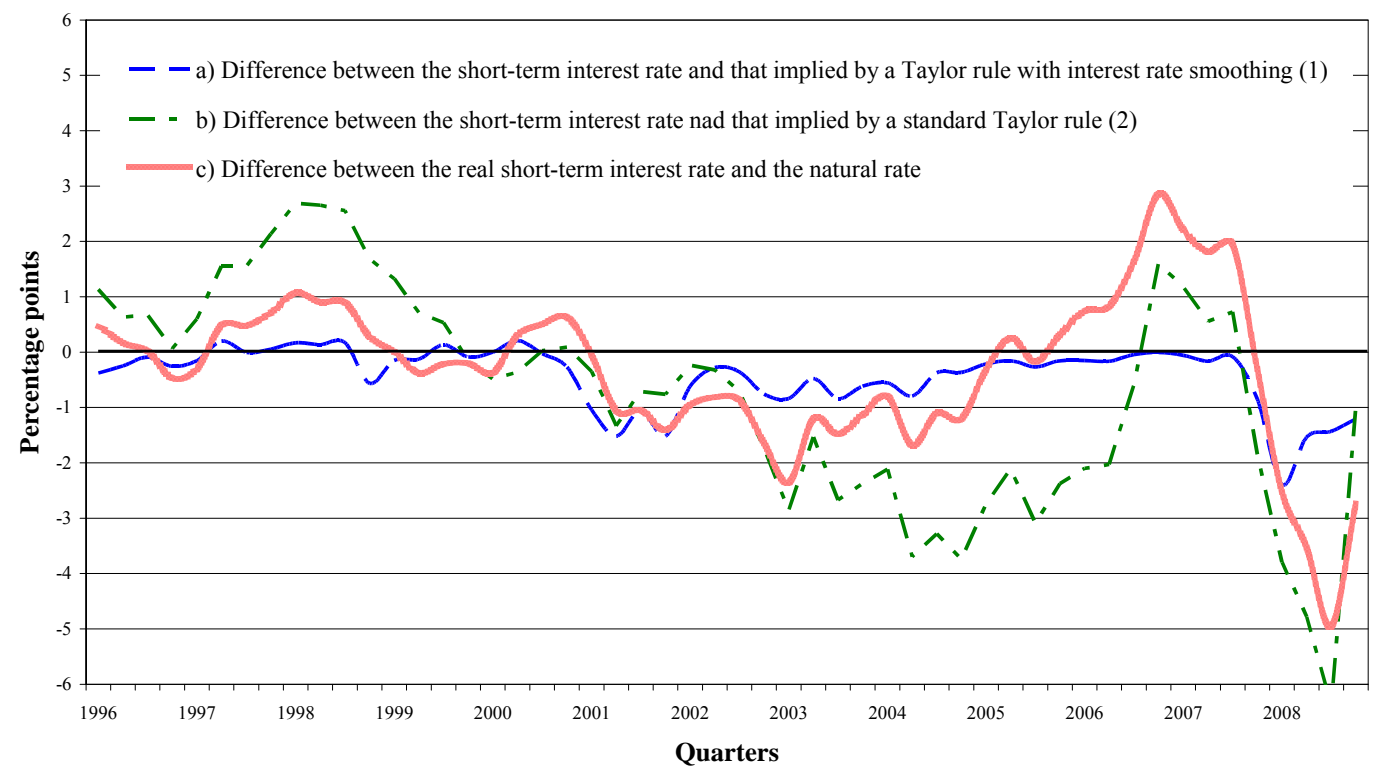

Source: Authors' calculation.

Notes: The Taylor rule is given by the formula $i_{\mathrm{t}}=\alpha+\beta_{\pi}\left(\pi_{\mathrm{t}}-\pi^{*}\right)+\beta_{\mathrm{y}}\left(y_{\mathrm{t}}-y_{\mathrm{t}}^{*}\right)+\gamma\left(i_{\mathrm{t}}-i_{\mathrm{t}-1}\right)$, where the natural rate $\alpha$ is calculated by means of a Hodrick and Prescott filter. (1) $\beta_{\pi}=1.5 ; \beta_{\mathrm{y}}=0.5 ; \gamma=0.9 ;$ (2) $\beta_{\pi}=0.5 ; \beta_{\mathrm{y}}=0.5 ; \gamma=0$. 
EXCESSIVE LENDING EXPANSION AND BANK RISK

(quarterly changes of EDF one year ahead; percentages)

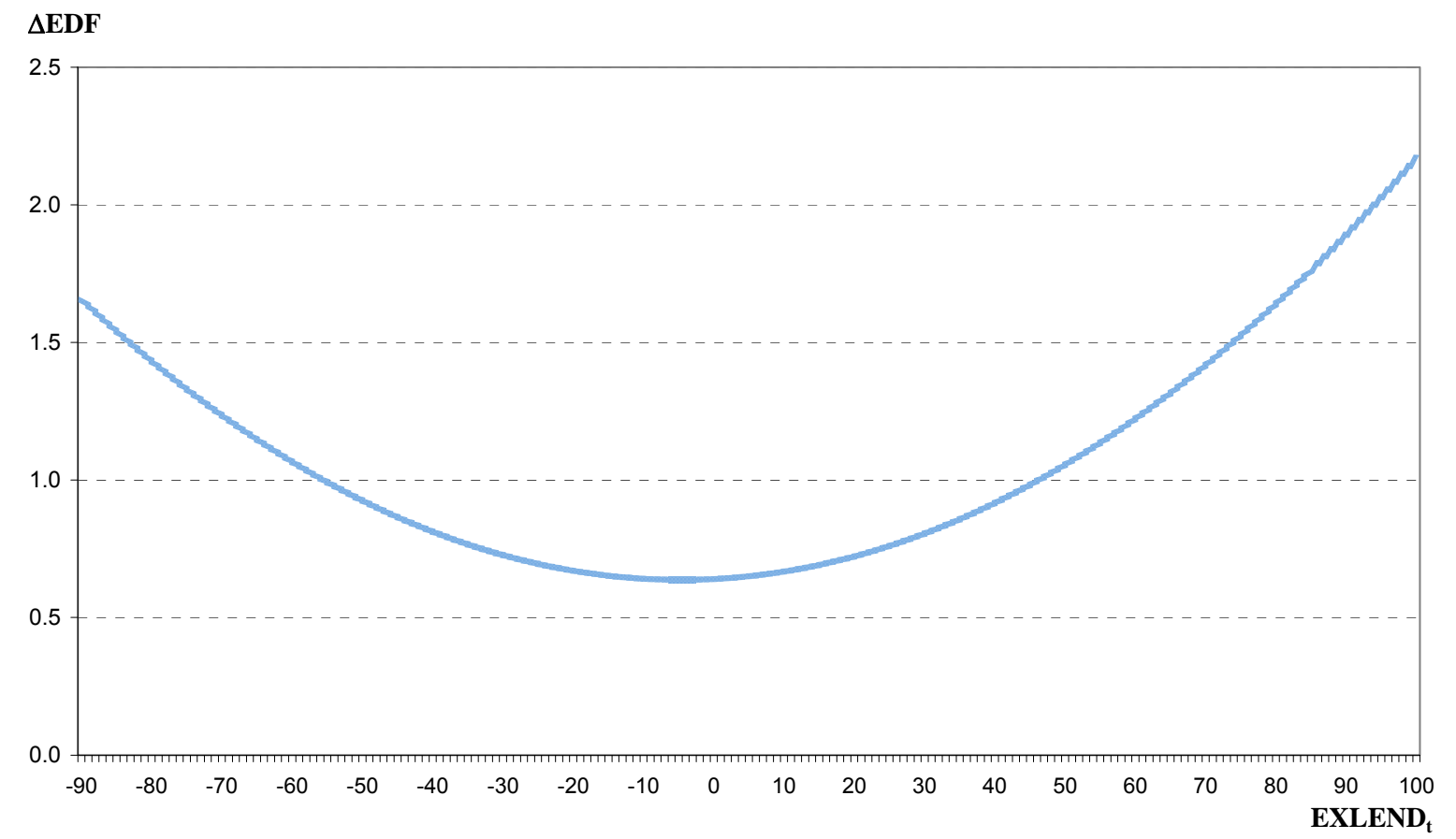

Source: Authors' calculations. The variable EXLEND represents excessive credit expansion (demeaned). 


\section{References}

Ackermann, C., Mc Enally, R. and Ravenscraft, D. (1999), “The Performance of Hedge Funds: Risk, Return, and Incentives", The Journal of Finance, Vol. 54, No. 3, pp. 833-874.

Adrian, T. and Shin, H.S. (2009a), "Money, Liquidity, and Monetary Policy", American Economic Review, Vol. 99, No. 2, pp. 600-605.

Adrian, T. and Shin, H.S. (2009b), "Financial Intermediation and Monetary Economics", Federal Reserve Bank of New York Staff Reports, No. 398.

Albertazzi U. and Gambacorta L. (2009), "Bank Profitability and the Business Cycle", Journal of Financial Stability, Vol. 5, pp. 393-409.

Arellano, M. and Bover, O. (1995), "Another Look at the Instrumental Variable Estimation of ErrorComponents Models", Journal of Econometrics, Vol. 68, pp. 29-51.

Barberis N., Shleifer A.and Vishny R. (1998), "A Model of Investor Sentiment", Journal of Financial Economics, Vol. 49, pp. 307-343.

Barth J.R., Caprio G. and Levine R. (2004), "Bank Regulation and Supervision: What Works Best?", Journal of Financial Intermediation, Vol. 13, pp. 205-248.

Beltratti A. and Stultz R.M. (2009), "Why Did Some Banks Perform Better During the Credit Crisis? A Cross-country Study of the Impact of Governance and Regulation", National Bureau of Economic Research Working Paper, No. 15180.

Benmelech E. and Dlugosz J. (2009), "The Credit Rating Crisis", National Bureau of Economic Research Working Paper, No. 5045.

Berger A.N., Bonime S.D., Covitz D.M. and Hancock D. (2000), "Why Are Bank Profits so Persistent? The Roles of Product Market Competition, Information Opacity and Regional Macroeconomic Shocks". Journal of Banking and Finance, Vol. 24, pp. 1203-1235.

Bernanke B. and Gertler M. (1989), "Agency Costs, Net Worth, and Business Fluctuations", American Economic Review, Vol. 79, No. 1, pp. 14-31.

Bernanke B., Gertler M. and Gilchrist S. (1996), "The Financial Accelerator and the Flight to Quality", The Review of Economics and Statistics, Vol. 48, pp. 1-15.

Blanco R., Brennan, S. and Marsh I.W. (2005), "An Empirical Analysis of the Dynamic Relation Between Investment-grade Bonds and Credit Default Swaps", The Journal of Finance, Vol. 60, No. 5, pp. 2255-2282.

Blundell, R., . and Bond, S. (1998), Initial conditions and moment restrictions in dynamic panel data models, Journal of Econometrics, Vol. 87, pp. 115-143.

Bollerslev T., R.Y. Chou and K.F. Kroner (1992), "ARCH Modeling in Finance: A Review of the Theory and Empirical Evidence", Journal of Econometrics, Vol. 52, pp. 5-59.

Borio C. and Drehmann M. (2009), "Assessing the Risk of Banking Crises - Revisited", BIS Quarterly Review, March, pp. 29-46.

Borio C., Furfine C., and Lowe P. (2001), "Procyclicality of the Financial System and Financial Stability: Issues and Policy Options", Bank for International Settlements Papers, No. 1.

Borio C. and Zhu H. (2008), "Capital Regulation, Risk-Taking and Monetary Policy: A Missing Link in the Transmission Mechanism?", Bank for International Settlements Working Paper, No. 268. 
Boyd J. and De Nicoló G. (2005), “The Theory of Bank Risk-Taking and Competition Revisited", Journal of Finance, Vol. 60, No. 3, pp. 1329-1343.

Brunnermeier M.K. (2001), Asset Pricing under Asymmetric Information - Bubbles, Crashes, Technical Analysis and Herding, Oxford, Oxford University Press.

Brunnermeier M.K. and Nagel S. (2004), "Hedge Funds and the Technology Bubble", Journal of Finance, Vol. 59, No. 5, pp. 2013-2040.

Campbell J.Y and Cochrane J. (1999) "By Force of Habit: a Consumption-based Explanation of Aggregate Stock Market Behavior", Journal of Political Economy, Vol. 107, pp. 205-251.

Campbell J.Y., Lettau M. Malkiel B.G. and Xu Y. (2001),"Have Individual Stocks Become More Volatile? An Empirical Exploration of Idiosyncratic Risk", Journal of Finance, Vol. 56, No. 1, pp 1-43.

Carletti, E. and Hartmann P. (2002) "Competition and Stability: What's Special About Banking?". European Central Bank Working Paper, No. 146.

Danielsson J., Shin H.S., and Zigrand J.P. (2004), "The Impact of Risk Regulation on Price Dynamics", Journal of Banking and Finance, Vol. 28, No. 5, pp. 1069-1087.

Dell'Ariccia G. and R. Marquez (2006), "Lending Booms and Lending Standards", Journal of Finance, Vol. 61, No. 5, pp. 2511-2546.

Diamond D.W. and Rajan R.G. (2009), "Illiquidity and Interest Rate Policy", NBER Working Paper Series, No. 15197.

Drucker S. and Puri M. (2009), "On Loan Sales, Loan Contracting, and Lending Relationships", Review of Financial Studies, Vol. 22, No. 7, pp. 2835-2872.

Dufresne P.C., Goldstein R. and Martin J.S. (2001), "The Determinants of Credit Spread Changes," Journal of Finance, Vol. 56, pp. 2177-2208.

Dwyer D. and Qu S. (2007), “EDFTM 8.0 Model Enhancements”, Moody's KMV.

Ehrmann M., Gambacorta L., Martínez-Pagés J., Sevestre P. and Worms A. (2003), "The Effects of Monetary Policy in the Euro Area", Oxford Review of Economic Policy, Vol. 19, pp 58-72.

Ellis L. (2008), "The Housing Meltdown: Why did it Happen in the United States?", Bank for International Settlements Working Paper, No. 259.

European Central Bank (2009), Financial Stability Review, June, Frankfurt.

Farhi E. and Tirole J. (2009), "Leverage and the Central Banker's Put", American Economic Review, Vol. 99, pp. 589-593.

Ferri G., Liu L.G. and Stiglitz J.E. (1999), "The Procyclical Role of Rating Agencies: Evidence from the East Asian Crisis", Economic Notes, Vol. 28, 3, pp. 335-355.

Fisher I. (1933), “The Debt Deflation Theory of Great Depressions”, Econometrica, pp.337-57.

Fostel A. and Geanakoplos J. (2008), "Leverage Cycles and Anxious Economy", American Economic Review, Vol. 98, No. 4, pp. 1211-1244.

Garlappi L., Uppal, R. and Wang, T. (2007), "Portfolio Selection with Parameter and Model Uncertainty: A Multi-Prior Approach”, Review of Financial Studies, Vol. 20, No 1, pp. 41-81.

Goddard J., Molyneux, P. and Wilson J.O.S. (2004). "Dynamics of Growth and Profitability in Banking". Journal of Money, Credit and Banking, Vol. 36, pp. 1069-1090. 
Greenspan A. (2005), "Risk Transfer and Financial Stability", Speech to the Federal Reserve Bank of Chicago's $41^{\text {st }}$ Annual Conference on Bank Structure, May 5 ${ }^{\text {th }}, 2005$.

Hayek F. A. (1939), Profits, Interest and Investment, London, Routledge, Kegan Paul.

International Monetary Fund (2009a), Global Financial Stability Review, April.

International Monetary Fund (2009b), "The Changing Housing Cycle and the Implications for Monetary Policy", World Economic Outlook, Chapter 3.

Ioannidou V., Ongena S. and Peydrò J.L. (2009), "Monetary Policy and Subprime Lending: A Tall Tale of Low Federal Funds Rates, Hazardous Loans, and Reduced Loans Spreads", European Banking Center Discussion Paper, No. 2009-04S.

Jiménez G., Ongena S., Peydrò-Alcalde J.L. and Saurina J. (2009), "Hazardous Times for Monetary Policy: What do Twenty-Three Million Bank Loans Say About the Effects of Monetary Policy on Credit Risk-Taking?", Banco de España Working Paper, No. 0833.

Jiménez G. and Saurina J. (2006), "Credit Cycles, Credit Risk, and Prudential Regulation", International Journal of Central Banking, Vol. 2, No. 2, pp. 65-98.

Kashyap A.K. and Stein J.C. (1995), "The Impact of Monetary Policy on Bank Balance Sheets", Carnegie Rochester Conference Series on Public Policy, Vol. 42, pp. 151-195.

Kashyap A.K., Stein J.C. and Wilcox D.W. (1993), "Monetary Policy and Credit Conditions: Evidence from the Composition of External Finance", The American Economic Review, Vol. 83, No.1, pp.78-98.

Kindleberger C.P. (1978), Manias, Panics and Crashes: A History of Financial Crises, New York, Basic Books.

Kishan R.P. and Opiela T.P. (2000), "Bank Size, Bank Capital, and the Bank Lending Channel", Journal of Money, Credit, and Banking, Vol. 32 , No. 1, pp. 121-141.

Kouwenberg R. and Ziemba W. (2007), "Incentives and Risk Taking in Hedge Funds", Journal of Banking and Finance, Vol. 31, No. 11, pp. 3291-3310.

Kwan S. and Eisenbeis R. (1997), "Bank Risk, Capitalization, and Operating Efficiency", Journal of Financial Services Research, Vol. 12, No. 2, pp. 117-131.

Longstaff F.A., Mithal S. and Neiss E. (2005), "Corporate Yield Spreads: Default Risk or Liquidity?: New Evidence from the Credit Default Swap Market", Journal of Finance, Vol. 60, No. 5, pp. 2213-2254.

Longstaff F.A. and Schwartz E. (1995), "A Simple Approach to Valuing Risky Fixed and Floating Rate Debt", Journal of Finance, Vol. 50, pp. 789-821.

Matutes C. and Vives X. (2000), "Imperfect competition, risk taking, and regulation in banking", European Economic Review, Vol. 44, pp. 1-34.

Merton R.C. (1974), "On the pricing of corporate debt: The risk structure of interest rates", Journal of Finance, Vol. 29, pp. 449-470.

Merton R.C., (1980), "On Estimating the Expected Return on the Market: An Exploratory Investigation", Journal of Financial Economics, Elsevier, Vol. 8, No. 4, pp. 323-361.

Munves D., Hamilton D. and Gokbayrak O. (2009), "The Performance of EDFs Since the Start of the Credit Crisis", Moody's Analytics, June.

Pagan A. and W. Schwert (1990), "Alternative Models for Conditional Stock Volatility", Journal of Econometrics, Vol. 45, pp. 267-90. 
Panetta F., Faeh T., Grande G., Ho C., King M., Levy A., Signoretti F.M., Taboga M. and Zaghini A. (2009), "An Assessment of Financial Sector Rescue Programmes", Bank for International Settlements Working Paper Papers, No. 48.

Parlour C. and Plantin G. (2007), "Loan Sales and Relationship Banking”, Journal of Finance, Vol. 53, pp. 99-129.

Rajan R.G. (2005), “Has Financial Development Made the World Riskier?”, National Bureau of Economic Research Working Paper Series, No. 11728.

Reinhart C.M. and Rogoff K.S. (2008), "Banking Crises: An Equal Opportunity Menace”, National Bureau of Economic Research Working Paper Series, No. 14587.

Ruckes M.E. (2004), "Bank Competition and Credit Standards", Review of Financial Studies, Vol. 17, No. 4, pp. 1073-1102,

Salas V. and Saurina J. (2003), "Deregulation, Market Power and Risk Behaviour in Spanish Banks", European Economic Review, Vol. 47, pp. 1061-1075.

Shin H.S. (2009), "Securitisation and Financial Stability”, Economic Journal, Vol. 119, pp. 309-332.

Shleifer A. and Vishny R.W. (1997), “The Limits of Arbitrage”, Journal of Finance, Vol. 52, pp. 3555.

Stein J.C. (1998), "An Adverse-Selection Model of Bank Asset and Liability Management with Implications for the Transmission of Monetary Policy", RAND Journal of Economics, Vol. 29, pp. 466-486.

Stiglitz J. (2009), Witness testimony before the Joint Economic Committee of Congress, $21^{\text {st }}$ April.

Svensson L.E.O. and Woodford M. (2004), "Implementing Optimal Policy through Inflation Forecast Targeting", in Bernanke B.S. and Woodford M. (eds.), The Inflation Targeting Debate, University of Chicago Press, Chicago.

Taylor J.B., ed. (2001), Monetary Policy Rules, National Bureau of Economic Research Studies in Business Cycles, Chicago, University of Chicago Press.

Taylor J.B. (2009), "The Financial Crisis and the Policy Responses: an Empirical Analysis of What Went Wrong", National Bureau of Economic Research Working Paper Series, No. 14631.

Van den Heuvel S.J. (2002), "Does Bank Capital Matter for Monetary Transmission?", Federal Reserve Bank of New York, Economic Policy Review, May, pp. 260-266. 